\title{
DO HIGHER HOUSE PRICES INDICATE HIGHER SAFETY? PRICE VOLATILITY RISK IN MAJOR CITIES IN TAIWAN
}

\author{
Fang-Ni CHU ${ }^{1}$, I-Chun TSAI (1D) ${ }^{2}{ }^{*}$ \\ ${ }^{1}$ Department of Money and Banking, National Kaohsiung University of Science and Technology, \\ Kaohsiung, Taiwan \\ ${ }^{2}$ Department of Finance, National University of Kaohsiung, No. 700, Kaohsiung University Rd., \\ Nanzih District, 811, Kaohsiung, Taiwan
}

Received 30 August 2019; accepted 15 November 2019

\begin{abstract}
This study investigates the housing market in Taiwan, an emerging market with relatively severe housing price inflation. Using data from the first quarter of 1991 to the second quarter of 2017 for four cities in Taiwan, this study compares the risk transmission and sources of their housing prices. The results reveal that Taipei-Taiwan's main financial hub-has the highest house prices among the four cities but maintains the lowest risk. Thus, in terms of price volatility risk, Taipei has the safest housing market among the studied cities. Other studies have discussed the potential housing price bubbles in regions with high housing prices but have been unable to explain the continual overheating of the housing markets. The findings of this study reveal that despite having the highest housing prices and the greatest potential bubble, the Taipei housing market has the lowest fluctuation risk, making it the safest market in terms of housing investment. The results of this study imply that Taiwan's economic development is excessively concentrated in Taipei, causing people to bear low returns and high risk when purchasing real estate in other areas, in turn increasing the continual imbalance between regional housing markets.
\end{abstract}

Keywords: Taiwanese housing market, housing market risk, the risk transmission, housing investment, the safest housing market.

\section{Introduction}

Whether areas with high housing price has higher or lower risk of house price fluctuation than other areas is dependent on whether the housing prices in these areas are overestimated. Coskun et al. (2020) note that housing price hikes often elicit suspicion of a housing bubble; however, test results obtained from housing price data collected in Turkey indicate that a sharp surge in housing price is supported by several reasonable factors. Theoretical studies examining whether housing prices are overestimated have mostly discussed the fundamental level of housing prices by using market equilibrium analysis. The literature can be roughly divided into three categories, the first of which is that on the theory of housing affordability, suggesting that housing prices are positively correlated with income and that income can thus be used to estimate reasonable housing prices (Hulchanski, 1995; Malpezzi, 1999). The second category of literature addresses the housing tenure choice model, which indicates that the cost of purchasing a house is equal to the rent when the market is in equilibrium and rent can thus be used to estimate the reasonable housing price (Himmelberg et al., 2005; Gallin, 2008). The third category is that on the housing supply-and-demand model (Hott \& Monnin, 2008; White, 2015), in which the factors affecting housing demand and supply are used as the fundamental factors affecting housing prices to estimate the long-term level of housing prices under supply and demand equilibrium.

Using different fundamental variables to determine whether housing prices are overvalued can lead to differing results. In addition, under certain market restrictions and irrational trader behaviors, a hike in housing prices may persist despite prices being considered to be overvalued. Moreover, de Vries and Boelhouwer (2009) report that the long-term and short-term changes in housing prices are inconsistent, with short-term fluctuations being caused by market inefficiencies, whereas long-term fluctuations are influenced by fundamental factors such as income.

Some recent studies have considered the volatility risk of housing prices from the perspective of investment, comparing the security of real estate with that of other

*Corresponding author. E-mail: ictsai@nuk.edu.tw 
assets under high investment risk, that is, observing which assets are safe havens for capital (Kopyl \& Lee, 2016). Numerous scholars have recently discussed the safe-haven characteristics of various different assets; however, most have focused on gold, currencies, and bond markets. ${ }^{1}$ Eraslan (2016) is among the few researchers to have discussed the concept of safe havens in regional housing markets. ${ }^{2}$ However, the safe-haven functions of real estate assets and their derivatives have been verified by early studies. For example, Hartzell et al. (1987) and Rubens et al. (1989) have proposed that real estate can be used for inflation hedging. Glascock et al. (2004) affirmed that real estate securities exhibited the most minor decline of all securities following a sharp fall in the stock market (U.S. stock prices slumped in October 1997); thus, real estate securities are more resistant to stock market falls than are state-owned enterprise stocks.

Surprisingly, despite such evidence of inflation-hedging and fall-resistant characteristics of real estate assets, few studies have discussed whether real estate assetswhich, similar to gold, are real assets-can be used as a safe haven. This gap is understated, likely because the safehaven functions of housing properties during financial crises such as bond and stock market crashes have been underestimated since the U.S. subprime mortgage crisis in 2007. However, regarding the question of whether the housing market in an economy's main financial hub is a safe haven for money, a positive answer was provided in a study related to London's housing market. Eraslan (2016) investigates whether economic uncertainty in some of the world's major economies, namely the Eurozone, the United States, China, and Russia, led to safe-haven demand for housing in London. Eraslan (2016) discovers that during periods of political uncertainty in the Eurozone and United States, safe-haven demand for housing in London increased.

\footnotetext{
1 For example, Ciner et al. (2013) used data from the United States and United Kingdom to analyze the relationship between main assets-specifically stocks, bonds, gold, oil, and exchange rates-and market performance; this analysis addressed whether these assets could be used as safe havens for one another. Kopyl and Lee (2016) compared 32 assets according to data from 1964-2014 and revealed that the U.S. treasuries and Japanese yen were the optimal safe-haven assets for U.S. investors. Andersen et al. (2007), Baele et al. (2010), and Dicle and Levendis (2017) have determined that bonds are the safest safe havens. Habib and Stracca (2012) suggested that currencies of financially open countries are robust against global risk. Ranaldo and Söderlind (2010) clearly indicated that the Japanese yen, Swiss franc, Pound sterling, and Euro all exhibited safe-haven characteristics.

2 The 32 assets proposed by Kopyl and Lee (2016) included real estate; however, the researchers used the S\&P/Case-Shiller Home Price Index to calculate house price returns. This research approach was employed to investigate whether a housing market as a whole is a safe haven for money; by contrast, Eraslan (2016) focused on housing market performance in the most competitive regions.
}

This paper discusses whether the aforementioned effects in London are valid only in developed economies, and whether the main financial hub of Taiwan-a developing economy that exhibits advanced financial development-can become a safe haven for the region. This study focuses on Taiwan, an emerging market with severely high house prices. Despite the research results obtained by Eraslan (2016) for the London housing market, numerous questions remain unresolved in terms of the risk of housing price volatility. Accordingly, the present study compares the housing price volatility in regions with high and low housing prices by using data from emerging markets.

Cesa-Bianchi et al. (2015) remark that compared with those in advanced economies, the housing prices in emerging economies exhibit rapid growth, high volatility, and less persistence, which indicate the high risk and specificity of housing prices in emerging economies. Scatigna et al. (2014) note that many emerging countriessuch as Lithuania, Bulgaria, Peru, South Korea, and Hong Kong-experienced considerable housing price volatility during the 1990s and 2000s. However, compared with the extensive literature on the volatility risk of housing prices in advanced economies (e.g., Lin \& Fuerst, 2014; Chandler \& Disney, 2014; Barros et al., 2015), few studies have investigated the housing market in emerging economies. Therefore, empirical findings provided by these studies on different emerging markets have been the main sources of reference for other emerging markets.

For example, according to Coskun et al. (2020), the sharp hike in housing prices in Turkey will affect the housing price dynamics and risks in the housing market. Therefore, Coskun et al. use data from 2007 to 2014 to test the real estate bubble in Turkey over two time intervals, and the results reveal that no bubble formed despite the Turkish housing market overvaluation during these two periods. Because of the lack of research on emerging housing markets, Coskun et al. (2020) propose recommendations on policies related to emerging housing markets on the basis of the situation in Turkey. Gholipour and Lean (2017) use data from selected provinces of Iran over the period of 1993-2014 to find out how real estate investors can gain diversification benefits from investing within the real estate sector across provinces of Iran, and point out that the findings should be valuable to domestic and foreign investors who are interested in the Iranian real estate sector, especially after the lifting of several international economic sanctions.

We analyze the housing markets of four major cities located in northern, central, and southern Taiwan; the risk transmission and risk sources related to house prices in these markets are also discussed based on data between the first quarter (quarters referred to as "Q1," "Q2," "Q3," and "Q4" hereafter) of 1991 and Q2 of 2017. By comparing the housing markets in these cities, we examine whether Taipei-the economic and financial development hub of Taiwan-exhibits safe-haven functions in the face of extremely high house prices. An economy's economic 
and financial development hub being able to serve as a safe haven for its housing market partially explains unbalanced housing resource allocation among regions; a region with highly concentrated development demonstrates higher safe-haven performance and more stable house prices than do relatively undeveloped regions, regardless of whether the housing market in such a region is overexuberant. This aspect is particularly critical in Asian and emerging markets. For example, Singapore and Hong Kong are markets with highly developed financial industries and high house prices; moreover, whether China-the world's largest emerging economy-can solve the excessively concentrated housing development in Beijing (capital) and Shanghai (main financial hub) is a complex question. Therefore, the evidence provided by this study may serve as a reference for policy development in emerging markets other than Taiwan.

Real estate differs from other financial and security assets in that demand for real estate comprises investment and consumption demand. The analysis of whether real estate is a relatively safe investment market should not only compare negative correlations among assets, as previous studies on safe havens did. For example, Kopyl and Lee (2016) only compared the negative correlations between house price returns and stock returns in different cities. Weng and Gong (2017) found that the housing returns of regions in China (that are in close geographic and economic proximities) exhibit not only strong comovement but also volatility spillovers. The present study focuses on house price returns and their volatility in cities and estimates a volatility impulse-response function (VIRF) of house price returns to compare the risk sources of each analyzed city's housing market and determine mutual influences among these housing markets. Section 1 introduces the research background and reviews relevant studies, section 2 describes the research model, section 3 presents the empirical results, and the last section concludes this paper.

\section{Background of Taiwanese housing markets and relevant studies}

Chen et al. (2007) highlighted three periods, namely 1972-1974, 1978-1980, and 1987-1989, when house prices in Taipei soared. The first soaring period was the result of an oil embargo that led to a sudden rise in oil prices and subsequent inflation and soaring construction costs. The second soaring period resulted from an increase in international oil prices. The third soaring period was attributed to excessively loose monetary policy. Studies have focused on problems in Taipei's housing market in analyses of Taiwan's housing bubbles. For example, Teng et al. (2013) used data from 1981 to 2010 to empirically estimate the real estate bubble sizes in Taipei-which had the largest housing bubble of all cities in Taiwan-and Hong Kong and examine the influence of land-use rights on housing bubbles. Figure 1 depicts average house prices (unit: thousand NT\$) per square meter in Taipei, New Tai-

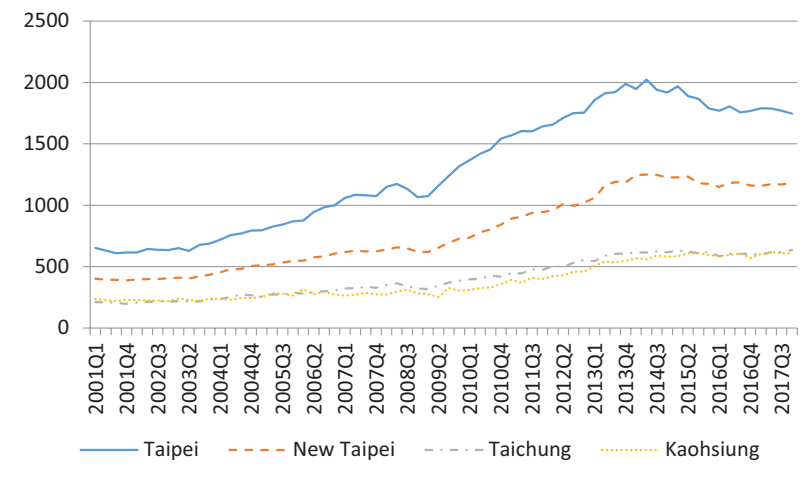

Figure 1. Average house prices

pei, Taichung, and Kaohsiung in 2001-2017. ${ }^{3}$ Regarding the average house prices throughout this period, that in New Taipei (which neighbors Taipei) was only $60.98 \%$ of that in Taipei, that in Taichung (central Taiwan) was only $31.57 \%$ of that in Taipei, and that in Kaohsiung (southern Taiwan) was only $29.23 \%$ of that in Taipei.

Since a high speed rail network connecting northern and southern Taiwan was opened in 2007, the housing bubble in Taipei has spilled over to markets in other cities. Andersson et al. (2010) argued that the new high speed rail connecting the seven metropolitan areas of Taiwan enhanced people's commuting behaviors and increased commutable distances. The same study revealed an empirical result suggesting that although the accessibility of the high speed rail significantly influenced house prices, its high ticket prices and people's entrenched living habits reduced intercity commuting among residents. Tsai (2018) investigated data from Q1, 1991 to Q3, 2016, and discovered unclear mutual convergence among house prices in large cities in Taiwan, indicating that these cities' housing markets operate independently of one another. Tsai (2018) also verified that improvements in transportation infrastructure had enhanced house price diffusion among cities in the preceding 10 years, and that the excessively high house prices in northern Taiwan had easily spilled over to Taichung's housing market. Moreover, since the high speed rail opened, house prices in northern Taiwan have become connected to those in southern Taiwan.

Based on the aforementioned studies, the Taiwanese housing bubble was generally limited in Taipei before the transportation infrastructure was improved (i.e., before 2007), and house prices in central and southern Taiwan rose with more convenient and faster transportation connecting northern and southern Taiwan. Tsai and Peng (2011) examined the existence of housing bubbles in four cities in Taiwan; according to the empirical results, the researchers confirmed the existence of Taiwanese housing bubbles and suggested that they were associated with expansionary monetary policy. They also explained Taiwanese housing bubbles before 1998 in relation to investment demand for housing, and associated Taiwanese housing

3 The data of average house prices are sourced from Sinyi Reality. 
bubbles after 1999 with interest rates. Tsai and Peng (2011) analyzed the influence of housing bubbles on family wellbeing in Taiwan and observed that because ethnically Chinese people preferred to own real estate, many forced themselves to buy houses even when house price bubbles existed, even though house price bubbles increase the difficulty of owning a house and in turn reduce people's quality of life.

Studies have conducted comprehensive discussions on market bubbles in Taiwan's overall housing market and its cities' housing markets. Therefore, the present study focuses on an unprecedented topic, namely whether a housing market in an emerging economy's main financial hub can serve as a safe haven for capital. The risk of housing market volatility is a particularly crucial topic for Taiwan. Chang and Chen (2015) note that Taiwan's housing prices have been growing rapidly over the past four decades and the development of the housing market has been closely related to that of Taiwan's financial system. Li (2002) remarks that the development of Taiwan's housing system reveals a close relationship between Taiwan's housing market and financial system, suggesting that a downturn in housing market prices will result in a recession and rising unemployment rate.

Compared with studies on housing bubbles, studies on housing market risks in Taiwan are few; only a small number have discussed the correlation between risks in housing markets and those in other markets due to high house prices and more substantial changes in Taiwanese housing markets over the preceding few years. Kang and Liu (2014) conducted quantile regression analysis on data from July 2005 to December 2010 to explore the influence of the 2008 financial crisis on house prices in China and Taiwan. Based on their results, house prices in Taiwan were more affected by the crisis when they were relatively high, whereas those in China were less affected by the crisis when they were relatively high. These results indicated that house prices had different influences on Taiwan and China's resistance to the financial crisis.

Liu and Chen (2016) explored nonlinear relationships and spillover effects among house prices, interest rates, and stock market prices based on monthly data of Taiwan from January 1985 to March 2009. The researchers observed a nonlinear relationship among the three variables, and that stock return volatility strongly affected interest rates. Additionally, they considered that changes in house prices can influence the occurrence of nonperforming loans, and changes in interest rates can directly affect the abilities of individuals and enterprises to pay loan interest; thus, comovement between house prices and stock prices increases. Accordingly, the risks of loan markets, housing markets, and stock markets are correlated. Vishwakarma (2015) used the data from March 2006 to November 2014 to investigate risk premiums for investors when housing markets in Taiwan, New York, and London changed. Vishwakarma (2015) found that the time-varying risk premium changed for the Taiwan real estate market with a new information set, however, no such evidence was found for the New York and London real estate markets. The aforementioned studies have identified differences between the risk in Taiwan's overall housing market and those in other markets but have not compared housing market risk in different cities in Taiwan. Therefore, the present study provides empirical results to fill this research gap.

In addition, this study also analyzes the sources of house price volatility risk in cities. Chen et al. (2007) and Tsai and Peng (2011) have indicated a close relationship between Taiwanese housing bubbles and monetary policy (money supply), whereas Liu and Chen (2016) suggested that Taiwan's overall housing market risk and monetary policy (interest rate) are closely related to stock market performance. Following previous studies, we adopted variables covering currency and financial markets, specifically money supply, interest rate, and stock index, to examine whether these variables are sources of housing market risk.

\section{Empirical model}

Focusing on housing properties, when analyzing markets with relatively stable house prices, the present study emphasizes house price returns and their volatilities, estimates a VIRF to compare sources of housing market risks in different cities, and investigates mutual influence among the markets of these cities. To explore a possible relationship between market returns and volatilities, a model to simultaneously estimate returns and volatilities is employed; specifically, we use vector autoregressive (VAR) models to understand the relationship between asset returns and employ multivariate generalized autoregressive conditional heteroscedasticity (MGARCH) to estimate correlations between asset return volatilities (risks). Earlier studies such as Karolyi (1995) have used VAR and MGARCH models to separately estimate the international transmission of stock returns and risks; however, this approach fails to distinguish whether a correlation between these two aspects is a result of returns or risks. A VARMGARCH model was recently established; this model quantifies correlations among markets more comprehensively because returns and risks are concurrently endogenously determined. A VAR-MGARCH model can be used in a multivariate model structure and distinguishes which variable-returns or volatilities-influences the other. Because of their strength for estimating returns and risks concurrently, these models are used extensively in various asset markets. For example, foreign exchange markets (Bekiros, 2014), spot and derivatives markets (Sogiakas \& Karathanassis, 2015), the U.S. crude oil, corn and plastics markets (Jiang et al., 2015), the Chinese real estate market (Tsai \& Chiang, 2018) and commodity futures markets (Andreasson et al., 2016).

Another advantage of using a VAR-MGARCH model is that incorporating heteroscedastic volatility into a VAR model enables more rigorous analysis of impulse responses, and thus such models have been rapidly developed and widely applied. Elder (2003) derived an impulse-response function for a vector autoregression with MGARCH er- 
rors, and Conrad and Karanasos (2006) further expounded on a VIRF. Using exchange rate as a sample, Hafner and Herwartz (2006) estimated a VIRF under an MGARCH model. Subsequently, Le Pen and Sévi (2010) expanded the model proposed by Hafner and Herwartz (2006) to obtain a forward electricity market's rate of return and volatility spillover. In addition to estimating market returns and risks, the present study discusses the sources of such risks by using impulse responses to quantify the influences of determinants on market risk when shocks occur in markets.

To clarify the intercity transmission of house price risks in Taiwan, this study uses VAR-MGARCH models and estimates VIRFs to analyze the influential factors of house price volatility risk. We divide our analysis into three steps. First, we estimate correlations between Taiwan's overall housing market risk and housing market risks in the aforementioned four cities. The model is presented as follows:

$\left[\begin{array}{c}r_{\text {city }, t} \\ r_{\text {Taiwan }, t}\end{array}\right]=\left[\begin{array}{l}\sum_{i=1}^{n} \theta_{11, i} r_{\text {city }, t-i} \\ \sum_{i=1}^{n} \theta_{21, i} r_{\text {city }, t-i}\end{array}\right]+\left[\begin{array}{l}\sum_{i=1}^{n} \theta_{12, i} r_{\text {Taiwan }, t-i} \\ \sum_{i=1}^{n} \theta_{22, i} r_{\text {Taiwan }, t-i}\end{array}\right]+\left[\begin{array}{c}\varepsilon_{1, t} \\ \varepsilon_{2, t}\end{array}\right]$,

where: $r_{\text {city }}$ is the house price index return rate (hereafter referred to as "house price return") in a city and $r_{\text {Taiwan }}$ denotes the house price return in Taiwan. To simplify the equation, let the house price vector be $\boldsymbol{r}^{\prime}=\left[r_{\text {city }} r_{\text {Taiwan }}\right]$. The conditional mean of house price return can be presented as follows:

$$
\begin{aligned}
& \boldsymbol{r}_{t}=\boldsymbol{A}_{0}+\boldsymbol{A}_{1} \boldsymbol{r}_{t-1}+\boldsymbol{A}_{2} \boldsymbol{r}_{t-2}+\ldots+\boldsymbol{A}_{p} \boldsymbol{r}_{t-p}+\boldsymbol{\varepsilon}_{t} ; \\
& \varepsilon_{t}\left|\Omega_{t-1}=\left[\begin{array}{c}
\varepsilon_{1, t} \\
\varepsilon_{2, t}
\end{array}\right]\right| \Omega_{t-1} \sim N\left(0, H_{t}\right) .
\end{aligned}
$$

The conditional variance of house price return is expressed as follows:

$$
\begin{aligned}
& H_{t}=\left[\begin{array}{ll}
\alpha_{11} & 0 \\
\alpha_{21} & \alpha_{22}
\end{array}\right]+\left[\begin{array}{ll}
\beta_{11} & \beta_{12} \\
\beta_{21} & \beta_{22}
\end{array}\right] e_{t-1} e_{t-1^{\prime}}\left[\begin{array}{ll}
\beta_{11} & \beta_{12} \\
\beta_{21} & \beta_{22}
\end{array}\right]+ \\
& {\left[\begin{array}{ll}
\gamma_{11} & \gamma_{12} \\
\gamma_{21} & \gamma_{22}
\end{array}\right] H_{t-1}\left[\begin{array}{ll}
\gamma_{11} & \gamma_{12} \\
\gamma_{21} & \gamma_{22}
\end{array}\right] .}
\end{aligned}
$$

Second, after estimating correlations between Taiwan's overall housing market risk and that in each of the four cities, we estimate the correlation in each pair within the four cities. In this step, we modify the house price return vector to $\boldsymbol{r}^{\prime}=\left[r_{\text {city } 1} r_{\text {city } 2}\right]$; the equations used to calculate the conditional mean and conditional variance of house price returns are identical to (3) and (4).

Finally, this study analyzes the sources of housing market risks in the four cities by using VAR-MGARCH models and subsequently discusses VIRFs. In this step, we modify the estimator vector to $\boldsymbol{r}_{\boldsymbol{x} y}{ }^{\prime}=\left[r_{x} r_{y}\right]$, where $r_{x}$ denotes the house price return of the city in question and $r_{y}$ is the volatility of the macroeconomic variable in ques- tion. Following previous studies, the present study uses three macroeconomic variables to analyze sources of risks; that is, we examine whether money supply, interest rate, and stock index are sources of housing market risks.

In summary, this study uses VAR-MGARCH models and VIRFs to quantitatively estimate house price volatility risks in four cities in Taiwan and discusses how such risks are affected by macroeconomic variables.

\section{Empirical results}

Table 1 lists the descriptive statistics of the adopted house price data, which comprise the house price indices of the aforementioned four cities (northern Taiwan: Taipei and New Taipei; central Taiwan: Taichung; southern Taiwan: Kaohsiung) and the overall house price index of Taiwan. The sample spans from Q1, 1991 to Q2, 2017. House price index data are sourced from Sinyi Reality. ${ }^{4}$ Figure 2 depicts the house price indices of the four cities and the overall house price index of Taiwan. Table 1 and Figure 2 show that Taipei's house price index had the largest volatility range and exhibited a predominantly increasing trend. The index grew from its lowest point of 90 in the preliminary period (1991) to 310 in Q2, 2014, and throughout the period, the house price in Taipei had a growth rate of $244 \%$. Concurrently, the house price in Kaohsiung had a growth rate of $130 \%$ and its index fell to 80 in 2000, which was lower than that in the preliminary period, indicating that Kaohsiung had the largest decline during the period of declining housing markets in 2000. Based on the information in Table 1, the unit root test showed that the house price indices of all four cities and the overall house price index of Taiwan were all first-order difference stationary. Hence, this study uses house price return to estimate empirical models. The Jarque-Bera statistics suggest that all data significantly reject the assumption of a normal distribution; the Ljung-Box statistics show that all variables exhibit autocorrelations.

Table 2 demonstrates three macroeconomic variables used to estimate the sources of housing market risks; the three variables are M2, interest rate for loans, ${ }^{5}$ and the Taiwan Stock Exchange Capitalization Weighted Stock Index. The macroeconomic variable data share the same time span as the house price data and are sourced from the Taiwan Economic Journal database. Because estimation of

\footnotetext{
4 Sinyi Reality collaborated with the College of Commerce in National Chengchi University to produce the indices by using the hedonic price method and Laspeyres index formula. This study, similar to most other studies (Bourassa et al., 2019; Pavlidis et al., 2016), uses the house price index rather than the average house price for trading when comparing the performance of the housing markets in different regions.

5 The interest rate data employed in this study are the benchmark interest rate for loans of the five major banks. The bank determines the home loan interest rate by summing the benchmark interest rate and risk premium, which is based on the credit of a borrower and the characteristics of the loan contract.
} 
Table 1. Descriptive statistics and tests of housing price indices

\begin{tabular}{|c|c|c|c|c|c|}
\hline Region & Taipei & New Taipei & Taichung & Kaohsiung & Taiwan \\
\hline Mean & 163.2969 & 164.2757 & 172.5527 & 143.6994 & 159.8291 \\
\hline $\mathrm{Mn}$ & 119.1494 & 126.0242 & 153.7809 & 127.2353 & 123.5087 \\
\hline Maximum & 310.2000 & 312.2800 & 300.4400 & 261.3700 & 297.7800 \\
\hline Minimum & 90.5871 & 96.9375 & 93.4410 & 80.2067 & 96.3929 \\
\hline Std. Dev. & 72.1238 & 71.0006 & 62.7501 & 50.5287 & 66.6413 \\
\hline Skewness & 0.8190 & 1.0165 & 0.8947 & 1.2216 & 0.9866 \\
\hline Kurtosis & 2.0458 & 2.4837 & 2.4954 & 3.1586 & 2.4057 \\
\hline $\mathrm{J}-\mathrm{B}$ & $\begin{array}{c}15.8699 \\
(0.0004)^{\star * *}\end{array}$ & $\begin{array}{c}19.4319 \\
(0.0001)^{\star * *}\end{array}$ & $\begin{array}{c}15.2649 \\
(0.0005)^{* * *}\end{array}$ & $\begin{array}{c}26.4754 \\
(0.0000)^{* * *}\end{array}$ & $\begin{array}{c}18.7579 \\
(0.0001)^{* * *}\end{array}$ \\
\hline PP & 0.0191 & 0.4825 & 0.8155 & 0.9511 & 0.5647 \\
\hline (level) & $(0.9576)$ & $(0.9854)$ & $(0.9939)$ & $(0.9959)$ & $(0.9881)$ \\
\hline PP & -9.0504 & -8.6893 & -11.0643 & -14.8407 & -6.7081 \\
\hline (dif.) & $(0.0000)^{\star * \star}$ & $(0.0000)^{\star * *}$ & $(0.0000)^{\star * *}$ & $(0.0000)^{* * *}$ & $(0.0000)^{* * *}$ \\
\hline \multirow[t]{2}{*}{ LB Q(1) } & 104.86 & 104.23 & 103.39 & 98.73 & 104.17 \\
\hline & $(0.0000)^{\star * \star}$ & $(0.0000)^{\star * *}$ & $(0.0000)^{* * *}$ & $(0.0000)^{* * *}$ & $(0.0000)^{* * *}$ \\
\hline \multirow[t]{2}{*}{ LB Q(5) } & 489.03 & 478.98 & 474.91 & 441.03 & 479.10 \\
\hline & $(0.0000)^{\star * *}$ & $(0.0000)^{\star * *}$ & $(0.0000)^{* * *}$ & $(0.0000)^{* * *}$ & $(0.0000)^{\star * \star}$ \\
\hline \multirow[t]{2}{*}{ LB Q(10) } & 871.66 & 833.93 & 825.30 & 720.74 & 836.96 \\
\hline & $(0.0000)^{\star * \star}$ & $(0.0000)^{\star * *}$ & $(0.0000)^{\star * *}$ & $(0.0000)^{* * *}$ & $(0.0000)^{* * *}$ \\
\hline \multirow[t]{2}{*}{ LB Q(15) } & 1122.40 & 1047.20 & 1025.60 & 846.46 & 1055.50 \\
\hline & $(0.0000)^{\star * *}$ & $(0.0000)^{\star * *}$ & $(0.0000)^{* * *}$ & $(0.0000)^{* * *}$ & $(0.0000)^{* * *}$ \\
\hline
\end{tabular}

Notes: This table shows the descriptive statistics and testing results of the properties of the housing price indices in the regional housing markets. J-B is the Jarque-Bera statistic which has a chi-square distribution under the null hypothesis of normal distribution. PP is the PP unit root test, which is adopted for testing the null hypothesis of a unit root in the series. The lag length of the unit root models is selected by using the Schwarz information criterion. L-B $\mathrm{Q}(n)$ are Ljung-Box statistics for testing whether there are serial correlation in series, $n$ denote lag term. The entry in parenthesis stands for the $p$-value. The symbols ${ }^{\star *}$ and ${ }^{* * *}$ denote significant at the $5 \%$ and $1 \%$ level.
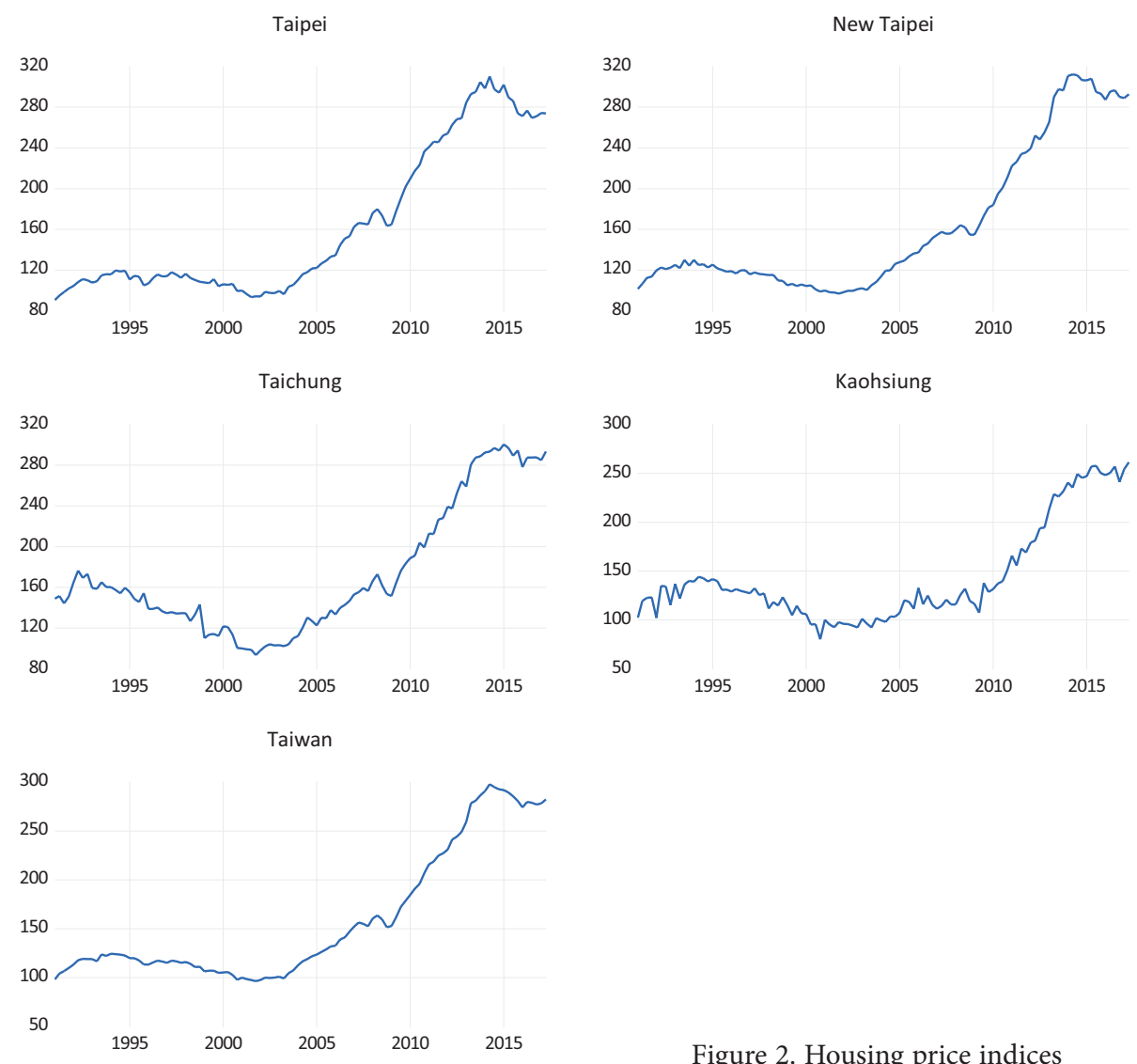

Figure 2. Housing price indices 
Table 2. Descriptive statistics and tests of macroeconomic variables

\begin{tabular}{|c|c|c|c|}
\hline Variable & $M 2 g$ & $\operatorname{Irg}$ & SPIg \\
\hline Mean & 0.0178 & -0.0128 & 0.0067 \\
\hline Median & 0.0152 & 0.0000 & 0.0136 \\
\hline Maximum & 0.0616 & 0.0656 & 0.4599 \\
\hline Minimum & -0.0097 & -0.5948 & -0.2947 \\
\hline Std. Dev. & 0.0138 & 0.0694 & 0.1373 \\
\hline Skewness & 0.5843 & -6.3979 & 0.3025 \\
\hline Kurtosis & 3.0465 & 50.5956 & 4.0892 \\
\hline$J-B$ & $\begin{array}{c}5.9841 \\
(0.0502)\end{array}$ & $\begin{array}{c}10627.21 \\
(0.0000)^{* * *}\end{array}$ & $\begin{array}{c}6.7910 \\
(0.0335)^{\star *}\end{array}$ \\
\hline PP & -7.8047 & -7.7663 & -10.0632 \\
\hline (level) & $(0.0000)^{* * *}$ & $(0.0000)^{* * *}$ & $(0.0000)^{\star \star \star \star}$ \\
\hline LB Q(1) & $\begin{array}{c}15.77 \\
(0.0000)^{\star * \star}\end{array}$ & $\begin{array}{c}7.14 \\
(0.0075)^{\star \star \star}\end{array}$ & $\begin{array}{c}0.01 \\
(0.9239)\end{array}$ \\
\hline LB Q(5) & $\begin{array}{c}89.47 \\
(0.0000)^{* * *}\end{array}$ & $\begin{array}{c}7.66 \\
(0.1762)\end{array}$ & $\begin{array}{c}15.67 \\
(0.0078)^{\star \star \star *}\end{array}$ \\
\hline LB Q(10) & $\begin{array}{c}137.49 \\
(0.0000)^{* * *}\end{array}$ & $\begin{array}{c}11.90 \\
(0.2916)\end{array}$ & $\begin{array}{c}25.74 \\
(0.0041)^{\star \star \star \star}\end{array}$ \\
\hline LB Q(15) & $\begin{array}{c}163.64 \\
(0.0000)^{* * *}\end{array}$ & $\begin{array}{c}15.13 \\
(0.4424)\end{array}$ & $\begin{array}{c}27.52 \\
(0.0248)^{\star \star}\end{array}$ \\
\hline
\end{tabular}

Notes: This table shows the descriptive statistics and testing results of the properties of the macroeconomic variables. There are three macroeconomic variables used in this paper. $M 2 g$ denotes the growth rate of money supply, Irg denotes the growth rate of interest rate, and SPIg denotes the stock market returns. J-B is the Jarque-Bera statistic which has a chi-square distribution under the null hypothesis of normal distribution. PP is the PP unit root test, which is adopted for testing the null hypothesis of a unit root in the series. The lag length of the unit root models is selected by using the Schwarz information criterion. L-B Q $(n)$ are Ljung-Box statistics for testing whether there are serial correlation in series, $n$ denote lag term. The entry in parenthesis stands for the $p$-value. The symbols ${ }^{* *}$ and ${ }^{* *}$ denote significant at the $5 \%$ and $1 \%$ level.

the empirical model requires stationary data, we list the growth rate data characteristics of the three variables in Table 2. Similar to the house price data result, these variable growth rates are all stationary and autocorrelated.

Table 3 presents the estimation results from step 1, namely the relationships between Taiwan's overall housing market and each of the four cities' housing markets, estimated by using VAR-MGARCH models. Regarding house price returns, all cities' housing markets exhibit autocorrelations, and despite being positively influenced by the housing market performance of Taiwan in the preceding quarter, only Taipei's housing market exhibits positive autocorrelation, whereas the markets of the other cities are all negatively autocorrelated. These findings reveal the momentum of house price growth in Taipei and imply an advantage of investing in Taipei's housing market. Regarding the other cities, Kaohsiung has an autocorrelation of -0.57 , revealing market correction that exhibits an immediate drop following a rising period. Furthermore, the house price returns of all cities lag behind Taiwan's overall housing market. Volatility coefficients $\beta_{12}, \beta_{21}, \gamma_{12}$, and $\gamma_{21}$, all suggest that Taiwan's overall housing market volatility is correlated to those of all four cities. To compare the generated test results, we compile causality-invariance and causality-in-mean test results obtained using the data in Table 3. The test results are presented in Table 4, which shows that Taiwan's overall housing market return unidirectionally leads each city's housing market return, and Taiwan's overall housing market volatility exhibits a bidirectional lead-lag relationship with each city's housing market volatility. Specifically, each city's housing market possesses abundant information related to volatility and risk, both of which affect Taiwan's overall housing market risk. To further compare the four cities' housing market risks, we illustrate the estimated volatilities of Taiwan's overall housing market and each city's housing market (Table 3) in Figure 3.

Table 3. The relationships between the Taiwanese and the city's housing markets

\begin{tabular}{|c|c|c|c|c|}
\hline City & Taipei & $\begin{array}{l}\text { New } \\
\text { Taipei }\end{array}$ & Taichung & Kaohsiung \\
\hline \multicolumn{5}{|c|}{ Mean equation } \\
\hline \multicolumn{5}{|c|}{ Variable: $r_{\text {city }}$} \\
\hline$r_{\text {city }, t-1}$ & $-0.3642^{\star * *}$ & $-0.3383^{\star * *}$ & $-0.4052^{\star * *}$ & $-0.5731^{\star \star *}$ \\
\hline$r_{\text {Taiwan }, t-1}$ & $0.8470^{* * *}$ & $0.8349^{\star * *}$ & $0.9100^{\star * *}$ & $1.0465^{\star * *}$ \\
\hline Constant & $0.7616^{\star * \star}$ & 0.3255 & 0.3252 & 0.6032 \\
\hline \multicolumn{5}{|c|}{ Variable: $r_{\text {Taiwan }}$} \\
\hline$r_{\text {city, } t-1}$ & 0.0905 & 0.2023 & -0.0403 & -0.0134 \\
\hline$r_{\text {Taiwan, } t-1}$ & $0.3262^{\star \star}$ & $0.2937^{\star *}$ & $0.4199^{\star \star \star}$ & $0.4407^{\star \star *}$ \\
\hline Constant & $0.8155^{\star * *}$ & 0.3579 & $0.6814^{\star \star *}$ & $0.4661^{\star *}$ \\
\hline \multicolumn{5}{|c|}{ Variance equation } \\
\hline$\alpha_{11}$ & $1.4224^{\star \star}$ & $1.5873^{\star \star \star}$ & $1.6011^{* * *}$ & 2.1606 \\
\hline$\alpha_{21}$ & 1.0908 & $1.6667^{\star * \star}$ & $0.8007^{\star \star \star}$ & $1.3179^{\star \star *}$ \\
\hline$\alpha_{22}$ & 0.0000 & 0.0000 & 0.0000 & 0.0000 \\
\hline$\beta_{11}$ & $-0.6381^{\star * *}$ & $-0.3344^{\star * \star}$ & $0.7843^{\star * *}$ & $0.5988^{\star * *}$ \\
\hline$\beta_{12}$ & $-0.3279^{\star *}$ & $-0.5142^{\star \star *}$ & 0.0975 & $0.1433^{* *}$ \\
\hline$\beta_{21}$ & $1.0345^{\star * *}$ & $1.0240^{\star * *}$ & $-0.6172^{\star * *}$ & $-0.5518^{\star *}$ \\
\hline$\beta_{22}$ & $0.7131^{\star * \star}$ & $1.0494^{\star \star \star}$ & 0.0195 & 0.2106 \\
\hline$\gamma_{11}$ & $1.1254^{\star * \star}$ & $0.4519^{\star * *}$ & $0.7239^{\star * *}$ & $0.6650^{* * *}$ \\
\hline$\gamma_{12}$ & $1.0047^{\star * *}$ & $-0.4892^{\star * \star}$ & -0.0009 & $-0.1823^{* * *}$ \\
\hline$\gamma_{21}$ & $-1.6695^{\star * *}$ & $-0.8074^{\star \star *}$ & -0.0854 & 0.6850 \\
\hline$\gamma_{22}$ & $-0.8557^{\star \star *}$ & 0.1427 & $0.9169^{\star \star \star}$ & $0.5894^{\star \star \star *}$ \\
\hline $\begin{array}{l}\text { Log } \\
\text { Likelihood }\end{array}$ & -440.4698 & -411.3914 & -512.6561 & -566.0414 \\
\hline
\end{tabular}

Notes: The table shows the relationship between the Taiwan housing market and the city's housing market. The estimated model is shown as follows.

$r_{\text {city }, t}=a_{11} r_{\text {city }, t-1}+a_{12} r_{\text {Taiwan },-1}+$ Constant $+\varepsilon_{1, t} ;$

$r_{\text {Taiwan }, t}=a_{21} r_{\text {city }, t-1}+a_{22} r_{\text {Taiwan }, t-1}+$ Constant $+\varepsilon_{2, t}$;

$\varepsilon_{t}=\left[\begin{array}{c}\varepsilon_{1, t} \\ \varepsilon_{2, t}\end{array}\right] \sim \mathrm{N}\left(0, H_{t}\right) ; H_{t}=\alpha^{\prime} \alpha+\sum_{k=1}^{K} \beta_{k}{ }^{\prime} \varepsilon_{t-1} \varepsilon_{t-1}{ }^{\prime} \beta_{k}+\sum_{k=1}^{K} \gamma_{k}{ }^{\prime} H_{t-1} \gamma_{k}$,

where: $r_{\text {city }}$ represents the returns of the city's housing market; $r_{\text {Taiwan }}$ represents the returns of the Taiwan housing market; $H_{t}$ is the conditional variance vector; $\alpha_{i i}, \beta_{i i}, \gamma_{i i}$ are the elements of the coefficient matrices. The lag length of the model is selected by using the Schwarz information criterion. The symbols ${ }^{* *}$ and ${ }_{* * *}$ denote significant at the $5 \%$ and $1 \%$ level. 
Table 4. Causality tests for the Taiwanese and the city's housing markets

\begin{tabular}{|c|c|c|c|c|c|c|}
\hline City & \multicolumn{3}{|c|}{ Taipei } & \multicolumn{3}{|c|}{ New Taipei } \\
\hline Null Hypothesis & $\chi_{(n)}^{2}$ & F-Statistic & $p$-value & $\chi_{(n)}^{2}$ & F-Statistic & $p$-value \\
\hline \multicolumn{7}{|l|}{ Causality in mean } \\
\hline City $-/ \rightarrow$ Taiwan & 0.7861 & & 0.3753 & 2.7871 & & 0.0950 \\
\hline Taiwan $-/ \rightarrow$ City & 18.0005 & & 0.0000 & 35.6519 & & 0.0000 \\
\hline \multicolumn{7}{|l|}{ Causality in variance } \\
\hline City $-/ \rightarrow$ Taiwan & 39.6368 & 19.8184 & 0.0000 & 1437.1031 & 718.5516 & 0.0000 \\
\hline Taiwan $-/ \rightarrow$ City & 49.2902 & 24.6451 & 0.0000 & 47.1908 & 23.5954 & 0.0000 \\
\hline City & \multicolumn{3}{|c|}{ Taichung } & \multicolumn{3}{|c|}{ Kaohsiung } \\
\hline Null Hypothesis & $\chi_{(n)}^{2}$ & F-Statistic & $p$-value & $\chi_{(n)}^{2}$ & F-Statistic & $p$-value \\
\hline \multicolumn{7}{|l|}{ Causality in mean } \\
\hline City $-/ \rightarrow$ Taiwan & 0.5576 & & 0.4552 & 0.0790 & & 0.7787 \\
\hline Taiwan $-/ \rightarrow$ City & 31.7920 & & 0.0000 & 26.6504 & & 0.0000 \\
\hline \multicolumn{7}{|l|}{ Causality in variance } \\
\hline City $-/ \rightarrow$ Taiwan & 12.6669 & 6.3334 & 0.0018 & 17.6638 & 8.8319 & 0.0001 \\
\hline Taiwan $-/ \rightarrow$ City & 8.9584 & 4.4792 & 0.0113 & 8.7342 & 4.3671 & 0.0127 \\
\hline
\end{tabular}

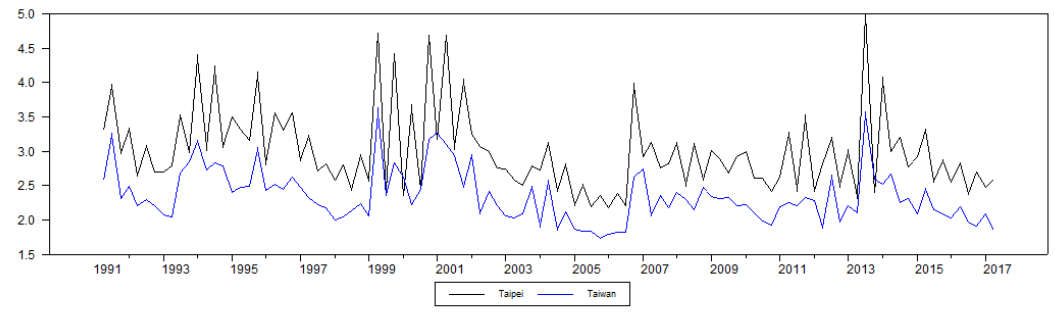

Conditional Volatility in Std Deviations-Taipe

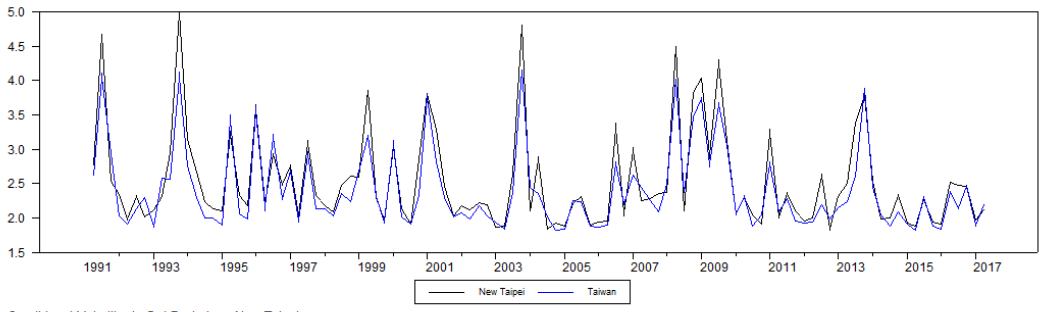

Conditional Volatility in Std Deviations-New Taipei

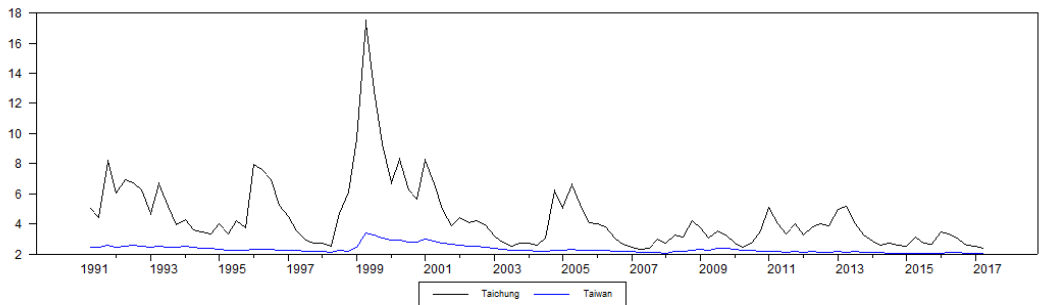

Conditional Volatility in Std Deviations-Taichung

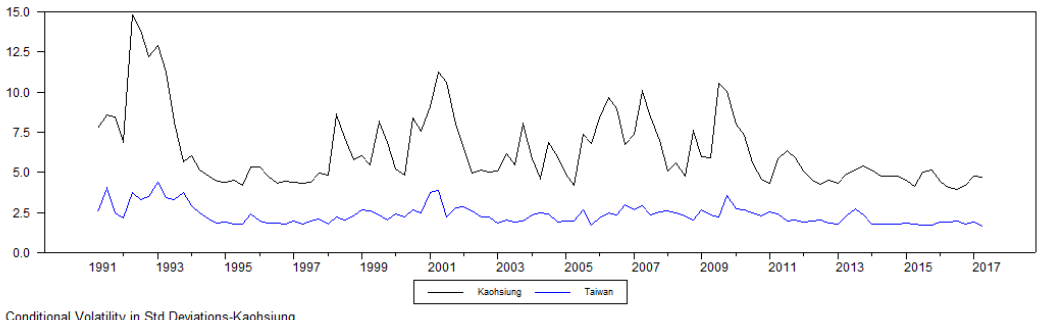

Conditional Volatility in Std Deviations-Kaohsiung

Figure 3. Conditional volatility 
Based on Figure 3, Taipei and New Taipei's housing price volatilities are similar to Taiwan's overall housing price volatility, whereas Taichung and Kaohsiung's volatilities are considerably higher than Taiwan's. These findings indicate that Taichung and Kaohsiung's housing markets both have notably higher total risk of conditional volatility than does Taiwan's overall housing market. Table 3 and Figure 3 reveal two advantages of using Taipei's housing market as a safe haven, namely relatively low total volatility risk and relatively strong increasing momentum (i.e., continuity). By contrast, Table 3 and Figure 3 demonstrate the high house price risk that people buying houses in Kaohsiung are subject to; people who own houses in Kaohsiung are faced with higher total volatility risk and short-term risks derived from immediate drops following periods of rising house prices. Such differences in risk may not affect people buying houses for self-residential purposes, whereas those buying houses for investment purposes-namely those expecting to gain profits from price differences by selling their houses in the future-are recommended to buy houses in Taipei.

Figure 4 presents the proportions of people buying houses for investment purposes in each of the four cities. ${ }^{6} \mathrm{Be}-$ sides investment, the other main purpose of buying a house is self-residence; therefore, higher investment demand for housing indicates lower self-residence demand for housing. Figure 4 shows that people in Taipei demonstrate the highest investment demand for housing; by contrast, people in Kaohsiung demonstrate the lowest investment demand for housing and buy houses primarily for self-residence. The empirical results reveal that Taipei has the highest house prices but the lowest house price volatility risk, whereas Kaohsiung has the lowest house prices but the highest house price volatility risk. These findings explain why people in Taipei have the highest investment demand for housing. Specifically, considering gains in profits from housing price differences, people buying houses in Taipei are subject to the lowest investment risks. By contrast, because in Kaohsiung, which exhibits high housing investment risk, people buy houses mainly for self-residence, they tend to accept such imbalanced high-risk low-return investments.

People's preferences for investment or self-residence in different regions may affect the characteristics of each region's housing market. Step 2 discusses the lead-lag relationship of returns and volatilities in each pair of cities within the four cities. Our estimation results are shown in Tables 5 and 6 . Table 5 presents the estimation results obtained using a VAR-MGARCH model, in which the house price return vector $\boldsymbol{r}^{\prime}=\left[\begin{array}{ll}r_{\text {city } 1} & r_{\text {city } 2}\end{array}\right]$. Table 6 shows the causality test results regarding returns and volatilities, which are obtained using the coefficients presented in Table 5. Table 5 reveals that all significant correlations between two cities are positive in terms of returns. Table 6 suggests that only Taipei demonstrates a return spillover effect to the other three cities. The housing market return in Taipei City has both lead and lag effects with that in New Taipei City. Taipei's

\footnotetext{
6 The data are sourced from Ministry of the interior of Taiwan.
}

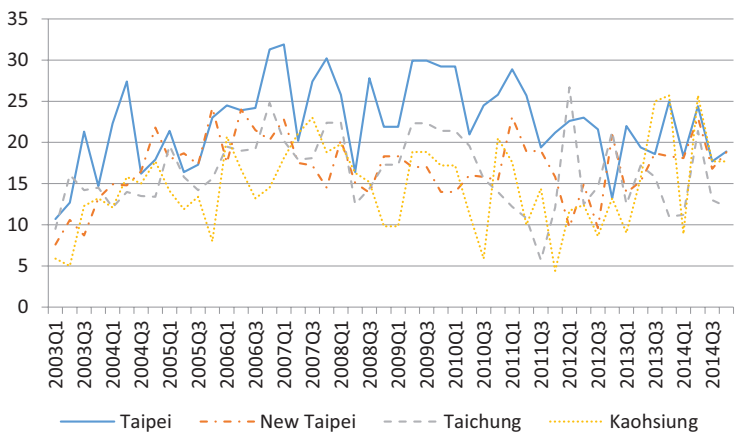

Figure 4. The proportion of buyers who purchased housing for investment

housing market volatility did not exhibit any lead-lag relationship with the volatility in New Taipei City. The housing market return in Taipei City leads those in Taichung and Kaohsiung. Regarding risk, Taipei's housing market transmits risk to Taichung and Kaohsiung's housing markets, whereas no city's housing market transmits risks to Taipei's housing market. These results provided in Tables 5 and 6 confirm the information leadership of Taipei's housing market among the four cities, its return spillover effect to the other three cities, and its lack of susceptibility to volatility risk in other housing markets. For more in-depth analysis, we depict the VIRFs for each pair of cities in Figure 5 to visualize the estimated influences of regional market shocks (Table 5). Based on the information in Figure 5, the shock of Taipei's housing market on the other three cities is larger than the shock of said three cities' housing markets on Taipei. According to the analysis result of step 2, we uncover the third advantage of using Taipei's housing market as a safe haven for investments in Taiwanese housing markets, namely a return spillover effect and lack of susceptibility to volatility risk in other cities' housing markets.

Finally, in step 3, this study investigates the influential factors of volatility risks in each city's housing market. First, we estimate VAR-MGARCH models by using a variable vector $\boldsymbol{r}_{x \boldsymbol{y}}{ }^{\prime}=\left[r_{x} r_{y}\right]$, where $r_{x}$ represents the house price return in the city in question and $r_{y}$ denotes the variation of macroeconomic variables, comprising money supply growth rate, rate of change in interest rates, and stock price return rate. The three variables and the estimated VAR-MGARCH models for the four cities are listed in Tables 7 (money supply growth rate), 8 (rate of change in interest rates), and 9 (stock price return rate).

For further analysis, we compile causality test results for macroeconomic variables in relation to house price returns in Tables 10, 11, and 12. Tables 7 and 10 indicate that money supply affects only the volatility aspect of house price returns and leads the four cities' house price return volatilities, meaning that changes in money supply influence risks in these housing markets. Figure 6 depicts the shock of money supply to each of the four cities' house price return volatilities and provides concrete evidence that an increase in money supply increases housing market risk and has a particularly noticeable influence on Kaohsiung's housing market. 
Table 5. VAR-MGARCH models of city pairs

\begin{tabular}{|c|c|c|c|c|c|c|}
\hline \multirow{2}{*}{ City2 City1 } & \multicolumn{3}{|c|}{ Taipei } & \multicolumn{2}{|c|}{ New Taipei } & \multirow{2}{*}{$\begin{array}{c}\text { Taichung } \\
\text { Kaohsiung }\end{array}$} \\
\hline & New Taipei & Taichung & Kaohsiung & Taichung & Kaohsiung & \\
\hline \multicolumn{7}{|c|}{ Variable: $r_{\text {city } 1}$} \\
\hline$r_{c i t y 1, t-1}$ & -0.0714 & 0.1316 & 0.1117 & 0.1068 & 0.1470 & -0.0778 \\
\hline$r_{\text {city } 2, t-1}$ & $0.5103^{* * *}$ & 0.0815 & 0.0015 & 0.0889 & 0.0243 & -0.0216 \\
\hline Constant & 0.5509 & $0.9019^{\star \star \star}$ & $0.9896^{* * *}$ & $1.0462^{\star \star \star}$ & $0.6961^{\star *}$ & $1.1291^{\star * *}$ \\
\hline \multicolumn{7}{|c|}{ Variable: $r_{\text {city2 }}$} \\
\hline$r_{\text {city } 1, t-1}$ & $0.3499^{* * *}$ & $0.5744^{\star * \star}$ & $0.5734^{* * *}$ & $0.6811^{\star * *}$ & $0.7928^{\star * *}$ & $0.3268^{\star * *}$ \\
\hline$r_{\text {city } 2, t-1}$ & -0.0619 & $-0.2708^{\star * *}$ & $-0.4367^{\star * *}$ & $-0.2440^{\star \star}$ & $-0.4919^{* * *}$ & $-0.3496^{\star * *}$ \\
\hline Constant & $0.4215^{\star \star}$ & 0.5765 & 0.8651 & 0.4456 & 0.7641 & 0.6053 \\
\hline$\alpha_{11}$ & $1.8097^{\star * *}$ & $1.2188^{\star *}$ & $3.1126^{* * *}$ & $0.8800^{\star *}$ & $1.8899^{\star * *}$ & $3.1479^{\star * *}$ \\
\hline$\alpha_{21}$ & $1.1544^{\star * *}$ & $1.6899^{\star * *}$ & 0.5234 & $1.5430^{\star * \star}$ & 1.3320 & 1.5325 \\
\hline$\alpha_{22}$ & 0.0000 & 0.0000 & 0.0000 & 0.0000 & 0.0000 & 0.0000 \\
\hline$\beta_{11}$ & $0.3446^{\star *}$ & 0.1813 & -0.1818 & 0.0223 & -0.0276 & $-0.8505^{\star * *}$ \\
\hline$\beta_{12}$ & 0.0534 & $-0.3224^{\star *}$ & 0.1257 & $-0.6058^{\star * *}$ & -0.1613 & $-0.5387^{\star * *}$ \\
\hline$\beta_{21}$ & -0.2086 & -0.0087 & 0.0322 & $0.2022^{\star * *}$ & 0.1331 & $-0.2369^{* * *}$ \\
\hline$\beta_{22}$ & $0.3336^{\star *}$ & $0.6467^{\star * *}$ & $0.5168^{\star * *}$ & $0.6378^{\star * *}$ & $0.5663^{* * *}$ & $0.3786^{* * *}$ \\
\hline$\gamma_{11}$ & $0.7838^{\star \star *}$ & $0.8766^{\star \star *}$ & 0.1696 & $0.9213^{\star * *}$ & $0.6268^{\star * *}$ & 0.0702 \\
\hline$\gamma_{12}$ & -0.0663 & -0.0976 & $-0.8892^{* * *}$ & -0.1066 & 0.5411 & $-0.7796^{\star * *}$ \\
\hline$\gamma_{21}$ & -0.0768 & 0.0549 & 0.0893 & -0.0483 & $-0.1776^{\star * \star}$ & -0.1335 \\
\hline$\gamma_{22}$ & $0.8348^{\star * *}$ & $0.7610^{* * *}$ & $0.7905^{\star * \star}$ & $0.7896^{\star * *}$ & $0.7356^{\star * *}$ & $0.6399^{* * *}$ \\
\hline $\begin{array}{l}\text { Log } \\
\text { Likelihood }\end{array}$ & -482.8755 & -557.7597 & -612.4362 & -541.2021 & -587.9718 & -644.3013 \\
\hline
\end{tabular}

Notes: The table shows the relationship between the two cities' housing markets. The estimated model is shown as follows. Let $r_{\text {city }}$ represents the returns of the city's housing market. $\boldsymbol{r}^{\prime}=\left[r_{\text {city } 1} r_{\text {city } 2}\right]$, then

$\boldsymbol{r}_{t}=\boldsymbol{A}_{0}+\boldsymbol{A}_{1} \boldsymbol{r}_{t-1}+\boldsymbol{A}_{2} \boldsymbol{r}_{t-2}+\ldots+\boldsymbol{A}_{p} \boldsymbol{r}_{t-p}+\varepsilon_{t} ; \varepsilon_{t}=\left[\begin{array}{c}\varepsilon_{1, t} \\ \varepsilon_{2, t}\end{array}\right] \sim \mathrm{N}\left(0, H_{t}\right) ; H_{t}=\alpha^{\prime} \alpha+\sum_{k=1}^{K} \beta_{k}{ }^{\prime} \varepsilon_{t-1} \varepsilon_{t-1}{ }^{\prime} \beta_{k}+\sum_{k=1}^{K} \gamma_{k}{ }^{\prime} H_{t-1} \gamma_{k}$,

where: $H_{t}$ is the conditional variance vector; $\alpha_{i j}, \beta_{i j}, \gamma_{i i}$ are the elements of the coefficient matrices. The lag length of the model is selected by using the Schwarz information criterion. The symbols ${ }^{* *}$ and ${ }^{* * *}$ denote significant at the $5 \%$ and $1 \%$ level.
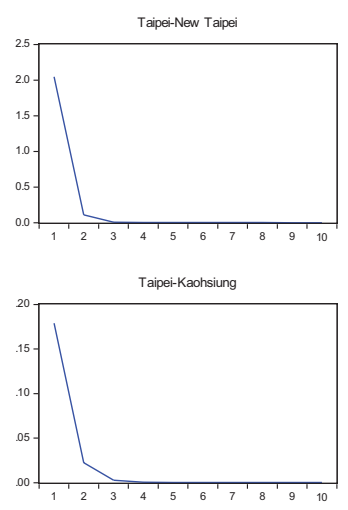

New Taipei-Kaohsiung

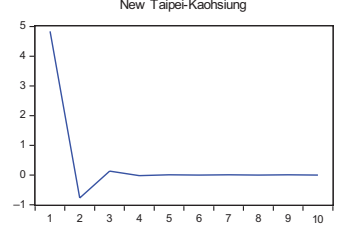

New Taipei-Taipe

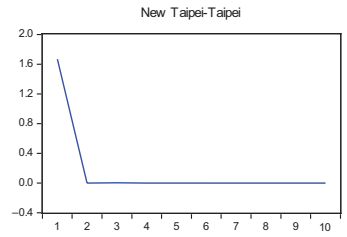

Kaohsiung-Taipei

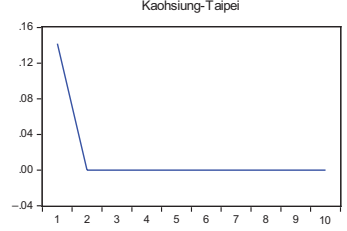

Kaohsiung-New Taipe

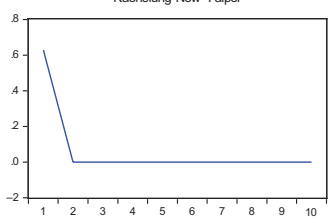

Taipe-Taichung

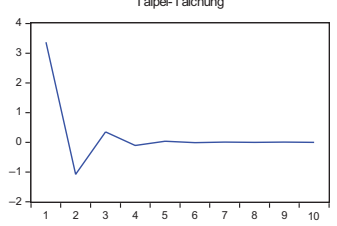

New Taipe-Taichung

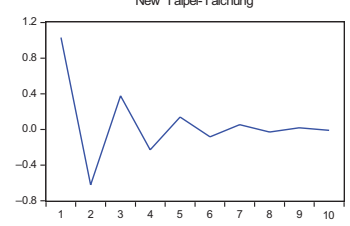

Taichung-Kaohsiung

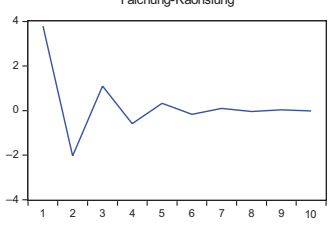

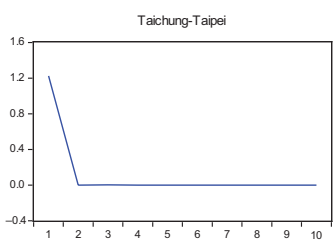

Taichung-New Taipel

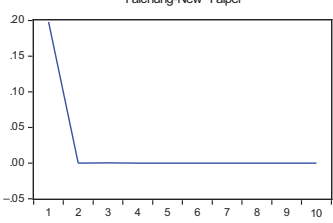

Kaohsiung-Taichung

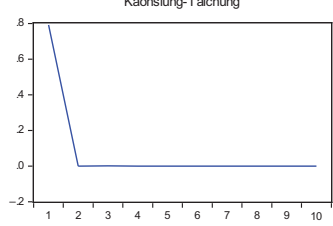

Figure 5. Relationship between city pairs 
Table 6. Causality tests for the two cities' housing markets

\begin{tabular}{|c|c|c|c|c|c|c|}
\hline \multirow{3}{*}{\begin{tabular}{|l} 
City2 Cityl \\
Null Hypothesis
\end{tabular}} & \multicolumn{3}{|c|}{ Taipei } & \multicolumn{3}{|c|}{ Taipei } \\
\hline & \multicolumn{3}{|c|}{ New Taipei } & \multicolumn{3}{|c|}{ Taichung } \\
\hline & $\chi_{(n)}^{2}$ & F-Statistic & $p$-value & $\chi_{(n)}^{2}$ & F-Statistic & $p$-value \\
\hline \multicolumn{7}{|l|}{ Causality in mean } \\
\hline City $1-/ \rightarrow$ City 2 & 22.5580 & & 0.0000 & 23.6856 & & 0.0000 \\
\hline City $2-/ \rightarrow$ City 1 & 21.3329 & & 0.0000 & 1.5620 & & 0.2114 \\
\hline \multicolumn{7}{|l|}{ Causality in variance } \\
\hline City $1-/ \rightarrow$ City 2 & 0.5043 & 0.2522 & 0.7771 & 8.3635 & 4.1817 & 0.0153 \\
\hline City $2-/ \rightarrow$ City 1 & 4.0397 & 2.0199 & 0.1327 & 2.0750 & 1.0375 & 0.3543 \\
\hline \multirow{2}{*}{ City2 } & \multicolumn{3}{|c|}{ Taipei } & \multicolumn{3}{|c|}{ New Taipei } \\
\hline & \multicolumn{3}{|c|}{ Kaohsiung } & \multicolumn{3}{|c|}{ Taichung } \\
\hline Null Hypothesis & $\chi_{(n)}^{2}$ & F-Statistic & $p$-value & $\chi_{(n)}^{2}$ & F-Statistic & $p$-value \\
\hline \multicolumn{7}{|l|}{ Causality in mean } \\
\hline City $1-/ \rightarrow$ City 2 & 9.3119 & & 0.0023 & 20.7548 & & 0.0000 \\
\hline City $2-/ \rightarrow$ City 1 & 0.0011 & & 0.9731 & 2.2691 & & 0.1320 \\
\hline \multicolumn{7}{|l|}{ Causality in variance } \\
\hline City $1-/ \rightarrow$ City 2 & 12.7383 & 6.3691 & 0.0017 & 16.8898 & 8.4449 & 0.0002 \\
\hline City $2-/ \rightarrow$ City 1 & 2.3328 & 1.1664 & 0.3115 & 8.1467 & 4.0734 & 0.0170 \\
\hline \multirow[t]{2}{*}{ City2 } & \multicolumn{3}{|c|}{ New Taipei } & \multicolumn{3}{|c|}{ Taichung } \\
\hline & \multicolumn{3}{|c|}{ Kaohsiung } & \multicolumn{3}{|c|}{ Kaohsiung } \\
\hline Null Hypothesis & $\chi_{(n)}^{2}$ & F-Statistic & $p$-value & $\chi_{(n)}^{2}$ & F-Statistic & $p$-value \\
\hline \multicolumn{7}{|l|}{ Causality in mean } \\
\hline City $1-/ \rightarrow$ City 2 & 22.3534 & & 0.0000 & 8.5920 & & 0.0034 \\
\hline City $2-/ \rightarrow$ City 1 & 0.4295 & & 0.5122 & 0.1723 & & 0.6781 \\
\hline \multicolumn{7}{|l|}{ Causality in variance } \\
\hline City $1-/ \rightarrow$ City 2 & 3.5413 & 1.7706 & 0.1702 & 26.9615 & 13.4807 & 0.0000 \\
\hline City $2-/ \rightarrow$ City 1 & 11.0163 & 5.5082 & 0.0041 & 11.5689 & 5.7845 & 0.0031 \\
\hline
\end{tabular}

Table 7. VAR-GARCH models of money supply and the housing market

\begin{tabular}{|c|c|c|c|c|}
\hline City & Taipei & New Taipei & Taichung & Kaohsiung \\
\hline \multicolumn{5}{|c|}{ Macroeconomic variable: $M 2 g$} \\
\hline \multicolumn{5}{|c|}{ Variable: $r_{x}$} \\
\hline$r_{x, t-1}$ & 0.1384 & $0.2246^{\star *}$ & -0.0580 & $-0.4453^{* * x}$ \\
\hline$r_{x, t-1}$ & 0.1194 & 0.1541 & -0.0546 & -0.7811 \\
\hline Constant & 0.7609 & $0.7779^{* *}$ & $1.3435^{\star *}$ & $2.5303^{* * *}$ \\
\hline \multicolumn{5}{|c|}{ Variable: $r_{y}$} \\
\hline$r_{y, t-1}$ & -0.0562 & -0.0667 & -0.0400 & 0.0121 \\
\hline$r_{y, t-1}$ & $0.2568^{\star * *}$ & $0.2390^{\star * *}$ & $0.345^{\star * *}$ & $0.2795^{\star * *}$ \\
\hline Constant & $1.1172^{\star * *}$ & $1.2892^{* * *}$ & $0.9633^{* * *}$ & $1.0811^{\star * *}$ \\
\hline$\alpha_{11}$ & 0.0004 & 0.5685 & 0.0000 & $3.8758^{\star * *}$ \\
\hline$\alpha_{21}$ & 0.000 & 0.0588 & 0.0000 & $-0.3227^{\star *}$ \\
\hline$\alpha_{22}$ & -0.0001 & 0.0000 & 0.0000 & 0.0000 \\
\hline
\end{tabular}


End of Table 7

\begin{tabular}{|l|c|c|c|c|}
\hline \multicolumn{1}{|c|}{ City } & Taipei & New Taipei & Taichung & Kaohsiung \\
\hline$\beta_{11}$ & 0.0614 & -0.0372 & $0.1881^{\star * *}$ & $0.6378^{\star * *}$ \\
$\beta_{12}$ & 0.0308 & $0.0809^{* *}$ & -0.0244 & -0.0123 \\
$\beta_{21}$ & $0.4222^{* * *}$ & $0.7370^{* * *}$ & $1.5064^{* * *}$ & 1.0890 \\
$\beta_{22}$ & $0.2008^{* *}$ & $0.2473^{* *}$ & -0.0499 & 0.0326 \\
$\gamma_{11}$ & $-0.9650^{\star * *}$ & $0.8526^{* * *}$ & 0.0749 & $0.3432^{* * *}$ \\
$\gamma_{12}$ & $0.0636^{* *}$ & -0.1970 & $-0.2559^{* * *}$ & $-0.1074^{* * *}$ \\
$\gamma_{21}$ & $0.7202^{* *}$ & -0.7553 & $-3.4629^{* * *}$ & $-2.0436^{* * *}$ \\
$\gamma_{22}$ & $0.9423^{* * *}$ & $-0.8387^{* * *}$ & -0.1077 & $-0.7964^{* * *}$ \\
\hline Log & -435.6751 & -414.2707 & -465.3358 & -511.1593 \\
Likelihood & & & & \\
\hline
\end{tabular}

Notes: The table shows the relationship between the city's housing market and the macroeconomic variable. The estimated model is shown as follows. Let $r_{x}$ represents the returns of the city's housing market, and $r_{y}$ represents the growth rate of the macroeconomic variable. $\boldsymbol{r}_{x y}{ }^{\prime}=\left[r_{x} r_{y}\right]$, then $\boldsymbol{r}_{x y, t}=\boldsymbol{A}_{0}+\boldsymbol{A}_{1} \boldsymbol{r}_{x y, t-1}+\boldsymbol{A}_{2} \boldsymbol{r}_{x y, t-2}+\ldots+\boldsymbol{A}_{p} \boldsymbol{r}_{x y, t-p}+\varepsilon_{t} ; \varepsilon_{t}=\left[\begin{array}{c}\varepsilon_{1, t} \\ \varepsilon_{2, t}\end{array}\right] \sim \mathrm{N}\left(0, H_{t}\right) ; H_{t}=\alpha^{\prime} \alpha+\sum_{k=1}^{K} \beta_{k}{ }^{\prime} \varepsilon_{t-1} \varepsilon_{t-1}{ }^{\prime} \beta_{k}+\sum_{k=1}^{K} \gamma_{k}{ }^{\prime} H_{t-1} \gamma_{k}$

where: $H_{t}$ is the conditional variance vector; $\alpha_{i i}, \beta_{i i}, \gamma_{i i}$ are the elements of the coefficient matrices; $M 2 g$ denotes the growth rate of money supply. The lag length of the model is selected by using the Schwarz information criterion. The symbols ${ }^{\star *}$ and ${ }^{\star * *}$ denote significant at the $5 \%$ and $1 \%$ level.

Table 8. VAR-GARCH models of interest rate and the housing market

\begin{tabular}{|c|c|c|c|c|}
\hline City & Taipei & New Taipei & Taichung & Kaohsiung \\
\hline \multicolumn{5}{|c|}{ Macroeconomic variable: $\operatorname{Irg}$} \\
\hline \multicolumn{5}{|l|}{ Variable: $r_{x}$} \\
\hline$r_{x, t-1}$ & 0.1400 & 0.1884 & $-0.1560^{* *}$ & $-0.4459^{\star * *}$ \\
\hline$r_{x, t-1}$ & -0.1282 & -0.0634 & 0.0102 & -0.0056 \\
\hline Constant & $0.7882^{\star *}$ & $0.7546^{\star *}$ & $1.8595^{\star * *}$ & 1.2256 \\
\hline \multicolumn{5}{|l|}{ Variable: $r_{y}$} \\
\hline$r_{y, t-1}$ & 0.3000 & 0.1994 & -0.0583 & 0.0751 \\
\hline$r_{y, t-1}$ & $0.4215^{\star * *}$ & $0.3884^{\star * *}$ & $0.1395^{\star * *}$ & $0.3592^{* * *}$ \\
\hline Constant & -1.1204 & -0.9638 & $0.6907^{\star \star *}$ & -0.8178 \\
\hline$a_{11}$ & 2.6060 & 0.0288 & $4.1132^{\star * *}$ & 1.0174 \\
\hline $\mathrm{a}_{21}$ & -0.8066 & $3.3175^{\star * \star}$ & 0.1333 & $-6.3748^{\star * *}$ \\
\hline$a_{22}$ & $6.3083^{* * *}$ & $5.5504^{\star * *}$ & 0.0000 & -0.0002 \\
\hline $\mathrm{b}_{11}$ & -0.0200 & 0.1987 & $0.9573^{\star * *}$ & $0.6704^{* * *}$ \\
\hline $\mathrm{b}_{12}$ & 0.1776 & 0.2709 & $0.9551^{* * *}$ & 0.1459 \\
\hline$b_{21}$ & $-0.1511^{\star \star}$ & -0.0912 & $-1.0643^{\star * \star}$ & 0.0507 \\
\hline$b_{22}$ & 0.2040 & 0.2067 & $2.2038^{\star * *}$ & 0.2766 \\
\hline$\gamma_{11}$ & 0.1297 & $0.7455^{\star *}$ & -0.0950 & $0.6424^{* * *}$ \\
\hline$\gamma_{12}$ & 0.0717 & -0.0551 & $-0.1411^{\star *}$ & 0.0388 \\
\hline$\gamma_{21}$ & -0.2479 & 0.2627 & 0.0324 & $-0.4107^{\star *}$ \\
\hline$\gamma_{22}$ & -0.1596 & -0.0122 & $0.1196^{\star * *}$ & -0.0212 \\
\hline $\begin{array}{l}\text { Log } \\
\text { Likelihood }\end{array}$ & -616.3461 & -602.7091 & -617.4333 & -691.4839 \\
\hline
\end{tabular}

Notes: The table shows the relationship between the city's housing market and the macroeconomic variable. The estimated model is shown as follows. Let $r_{x}$ represents the returns of the city's housing market, and $r_{y}$ represents the growth rate of the macroeconomic variable. $\boldsymbol{r}_{x y}{ }^{\prime}=\left[r_{x} r_{y}\right]$, then $\boldsymbol{r}_{x y, t}=\boldsymbol{A}_{0}+\boldsymbol{A}_{1} \boldsymbol{r}_{x y, t-1}+\boldsymbol{A}_{2} \boldsymbol{r}_{x y, t-2}+\ldots+\boldsymbol{A}_{p} \boldsymbol{r}_{x y, t-p}+\varepsilon_{t} ; \varepsilon_{t}=\left[\begin{array}{l}\varepsilon_{1, t} \\ \varepsilon_{2, t}\end{array}\right] \sim \mathrm{N}\left(0, H_{t}\right) ; H_{t}=\alpha^{\prime} \alpha+\sum_{k=1}^{K} \beta_{k}{ }^{\prime} \varepsilon_{t-1} \varepsilon_{t-1}{ }^{\prime} \beta_{k}+\sum_{k=1}^{K} \gamma_{k}{ }^{\prime} H_{t-1} \gamma_{k}$,

where: $H_{t}$ is the conditional variance vector; $\alpha_{i i}, \beta_{i i}, \gamma_{i i}$ are the elements of the coefficient matrices; Irg denotes the growth rate of interest rate. The lag length of the model is selected by using the Schwarz information criterion. The symbols ${ }^{* *}$ and ${ }^{* * *}$ denote significant at the $5 \%$ and $1 \%$ level. 
Table 9. VAR-GARCH models of the stock and housing markets

\begin{tabular}{|c|c|c|c|c|}
\hline City & Taipei & New Taipei & Taichung & Kaohsiung \\
\hline \multicolumn{5}{|c|}{ Macroeconomic variable: SPIg } \\
\hline \multicolumn{5}{|c|}{ Variable: $r_{x}$} \\
\hline$r_{x, t-1}$ & 0.0632 & 0.1483 & -0.0282 & $-0.4113^{\star * *}$ \\
\hline$r_{x, t-1}$ & $0.0628^{\star *}$ & $0.0623^{\star * *}$ & $0.1171^{\star * *}$ & $0.0896^{\star *}$ \\
\hline Constant & $1.0518^{\star * *}$ & $1.0175^{\star * *}$ & 0.5821 & 0.9747 \\
\hline \multicolumn{5}{|l|}{ Variable: $r_{y}$} \\
\hline$r_{y, t-1}$ & 0.2132 & 0.0611 & -0.1003 & -0.1163 \\
\hline$r_{y, t-1}$ & 0.0269 & 0.0701 & 0.0192 & 0.0605 \\
\hline Constant & 0.72 & 1.7842 & 1.3495 & 1.0462 \\
\hline$\alpha_{11}$ & $2.7345^{\star \star \star}$ & $2.0712^{* * *}$ & 1.4540 & 0.9294 \\
\hline$\alpha_{21}$ & 2.0821 & 2.2886 & -0.1593 & -2.9295 \\
\hline$\alpha_{22}$ & 2.1095 & 0.0000 & 0.0000 & 0.0000 \\
\hline$\beta_{11}$ & 0.0422 & 0.0348 & $0.6223^{\star * *}$ & $0.3221^{\star * *}$ \\
\hline$\beta_{12}$ & $-0.8986^{\star *}$ & -0.0645 & -0.2586 & $-0.5387^{\star * *}$ \\
\hline$\beta_{21}$ & $0.0868^{\star *}$ & $0.1014^{* * *}$ & 0.0128 & 0.0672 \\
\hline$\beta_{22}$ & $0.6407^{\star \star *}$ & $0.6118^{\star * *}$ & $0.3170^{\star *}$ & $0.4634^{\star \star \star}$ \\
\hline$\gamma_{11}$ & -0.3466 & 0.2308 & $0.7746^{\star * *}$ & $0.8553^{\star * *}$ \\
\hline$\gamma_{12}$ & -0.4867 & 0.3895 & $0.4719^{\star * *}$ & $0.6032^{\star * *}$ \\
\hline$\gamma_{21}$ & -0.0138 & $-0.0773^{\star * *}$ & -0.0375 & $-0.1742^{\star * *}$ \\
\hline$\gamma_{22}$ & $0.7901^{* * *}$ & $0.7850^{\star * *}$ & $0.8997^{* * *}$ & $0.7485^{\star * \star}$ \\
\hline $\begin{array}{l}\text { Log } \\
\text { Likelihood }\end{array}$ & -673.3084 & -654.4325 & -713.7948 & -750.1899 \\
\hline
\end{tabular}

Notes: The table shows the relationship between the city's housing market and the macroeconomic variable. The estimated model is shown as follows. Let $r_{x}$ represents the returns of the city's housing market, and $r_{y}$ represents the growth rate of the macroeconomic variable. $\boldsymbol{r}_{x y}{ }^{\prime}=\left[r_{x} r_{y}\right]$, then $\boldsymbol{r}_{x y, t}=\boldsymbol{A}_{0}+\boldsymbol{A}_{1} \boldsymbol{r}_{x y, t-1}+\boldsymbol{A}_{2} \boldsymbol{r}_{x y, t-2}+\ldots+\boldsymbol{A}_{p} \boldsymbol{r}_{x y, t-p}+\varepsilon_{t} ; \varepsilon_{t}=\left[\begin{array}{c}\varepsilon_{1, t} \\ \varepsilon_{2, t}\end{array}\right] \sim \mathrm{N}\left(0, H_{t}\right) ; H_{t}=\alpha^{\prime} \alpha+\sum_{k=1}^{K} \beta_{k}{ }^{\prime} \varepsilon_{t-1} \varepsilon_{t-1}{ }^{\prime} \beta_{k}+\sum_{k=1}^{K} \gamma_{k}{ }^{\prime} H_{t-1} \gamma_{k}$

where: $H_{t}$ is the conditional variance vector; $\alpha_{i i}, \beta_{i i}, \gamma_{i i}$ are the elements of the coefficient matrices; SPIg denotes the stock market returns. The lag length of the model is selected by using the Schwarz information criterion. The symbols ${ }^{* *}$ and ${ }^{* *}$ denote significant at the $5 \%$ and $1 \%$ level.

Table 10. Relationship between the money supply and the housing market

\begin{tabular}{|c|c|c|c|c|c|c|}
\hline & \multicolumn{3}{|c|}{ Taipei-Money supply } & \multicolumn{3}{|c|}{ New Taipei-Money supply } \\
\hline Null Hypothesis & $\chi_{(n)}^{2}$ & F-Statistic & $p$-value & $\chi_{(n)}^{2}$ & F-Statistic & $p$-value \\
\hline \multicolumn{7}{|l|}{ Causality in mean } \\
\hline City $-/ \rightarrow$ Variable & 3.3798 & & 0.0660 & 3.3341 & & 0.0679 \\
\hline Variable $-I \rightarrow$ City & 0.2632 & & 0.6080 & 0.9322 & & 0.3343 \\
\hline \multicolumn{7}{|l|}{ Causality in variance } \\
\hline City $-/ \rightarrow$ Variable & 9.4906 & 4.7453 & 0.0087 & 10.8560 & 5.4280 & 0.0044 \\
\hline Variable $-/ \rightarrow$ City & 11.3857 & 5.6929 & 0.0034 & 12.6067 & 6.3033 & 0.0018 \\
\hline & \multicolumn{3}{|c|}{ Taichung-Money supply } & \multicolumn{3}{|c|}{ Kaohsiung-Money supply } \\
\hline Null Hypothesis & $\chi_{(n)}^{2}$ & F-Statistic & $p$-value & $\chi_{(n)}^{2}$ & F-Statistic & $p$-value \\
\hline \multicolumn{7}{|l|}{ Causality in mean } \\
\hline City $-/ \rightarrow$ Variable & 3.2076 & & 0.0733 & 0.5942 & & 0.4408 \\
\hline Variable $-/ \rightarrow$ City & 0.0250 & & 0.8745 & 3.0456 & & 0.0810 \\
\hline \multicolumn{7}{|l|}{ Causality in variance } \\
\hline City $-/ \rightarrow$ Variable & 124.8650 & 62.4325 & 0.0000 & 38.8817 & 19.4408 & 0.0000 \\
\hline Variable $-/ \rightarrow$ City & 131.2031 & 65.6015 & 0.0000 & 88.5722 & 44.2861 & 0.0000 \\
\hline
\end{tabular}


Table 11. Relationship between the interest rate and the housing market

\begin{tabular}{|c|c|c|c|c|c|c|}
\hline & \multicolumn{3}{|c|}{ Taipei-Interest rate } & \multicolumn{3}{|c|}{ New Taipei-Interest rate } \\
\hline Null Hypothesis & $\chi_{(n)}^{2}$ & F-Statistic & $p$-value & $\chi_{(n)}^{2}$ & F-Statistic & $p$-value \\
\hline \multicolumn{7}{|l|}{ Causality in mean } \\
\hline City $-/ \rightarrow$ Variable & 2.2936 & & 0.1299 & 0.8514 & & 0.3561 \\
\hline Variable $-I \rightarrow$ City & 1.9778 & & 0.1596 & 1.2299 & & 0.2674 \\
\hline \multicolumn{7}{|l|}{ Causality in variance } \\
\hline City $-/ \rightarrow$ Variable & 0.3491 & 0.1746 & 0.8398 & 0.7456 & 0.3728 & 0.6888 \\
\hline Variable $-/ \rightarrow$ City & 4.7748 & 2.3874 & 0.0919 & 4.6400 & 2.3200 & 0.0983 \\
\hline & \multicolumn{3}{|c|}{ Taichung-Interest rate } & \multicolumn{3}{|c|}{ Kaohsiung-Interest rate } \\
\hline Null Hypothesis & $\chi_{(n)}^{2}$ & F-Statistic & $p$-value & $\chi_{(n)}^{2}$ & F-Statistic & $p$-value \\
\hline \multicolumn{7}{|l|}{ Causality in mean } \\
\hline City $-/ \rightarrow$ Variable & 2.7827 & & 0.0953 & 0.8526 & & 0.3558 \\
\hline Variable $-/ \rightarrow$ City & 0.0370 & & 0.8475 & 0.0051 & & 0.9431 \\
\hline \multicolumn{7}{|l|}{ Causality in variance } \\
\hline City $-/ \rightarrow$ Variable & 129.0262 & 64.5131 & 0.0000 & 1.1494 & 0.5747 & 0.5629 \\
\hline Variable $-/ \rightarrow$ City & 14.2209 & 7.1105 & 0.0008 & 4.2941 & 2.1470 & 0.1168 \\
\hline
\end{tabular}

Table 12. Relationship between the stock and housing markets

\begin{tabular}{|c|c|c|c|c|c|c|}
\hline \multirow[b]{2}{*}{ Null Hypothesis } & \multicolumn{3}{|c|}{ Taipei-Stock market } & \multicolumn{3}{|c|}{ New Taipei-Stock market } \\
\hline & $\chi_{(n)}^{2}$ & F-Statistic & $p$-value & $\chi_{(n)}^{2}$ & F-Statistic & $p$-value \\
\hline \multicolumn{7}{|l|}{ Causality in mean } \\
\hline City $-/ \rightarrow$ Variable & 0.4814 & & 0.4878 & 0.0447 & & 0.8325 \\
\hline Variable $-/ \rightarrow$ City & 5.2109 & & 0.0224 & 7.2144 & & 0.0072 \\
\hline \multicolumn{7}{|l|}{ Causality in variance } \\
\hline City $-/ \rightarrow$ Variable & 5.0583 & 2.5292 & 0.0797 & 0.1469 & 0.0734 & 0.9292 \\
\hline Variable-/ $\rightarrow$ City & 5.4439 & 2.7220 & 0.0657 & 18.5136 & 9.2568 & 0.0001 \\
\hline & \multicolumn{3}{|c|}{ Taichung-Stock market } & \multicolumn{3}{|c|}{ Kaohsiung-Stock market } \\
\hline Null Hypothesis & $\chi_{(n)}^{2}$ & F-Statistic & $p$-value & $\chi_{(n)}^{2}$ & F-Statistic & $p$-value \\
\hline \multicolumn{7}{|l|}{ Causality in mean } \\
\hline City $-/ \rightarrow$ Variable & 0.2310 & & 0.6308 & 0.6907 & & 0.4059 \\
\hline Variable $-/ \rightarrow$ City & 20.9875 & & 0.0000 & 4.1246 & & 0.0423 \\
\hline \multicolumn{7}{|l|}{ Causality in variance } \\
\hline City $-/ \rightarrow$ Variable & 20.2166 & 10.1083 & 0.0000 & 24.0986 & 12.0493 & 0.0000 \\
\hline Variable $-/ \rightarrow$ City & 2.2892 & 1.1446 & 0.3184 & 20.4527 & 10.2264 & 0.0000 \\
\hline
\end{tabular}

Tables 8 and 11 reveal that changes in interest rates have a relatively minor influence on Taiwan's house price returns because this influence is limited to volatility. Specifically, changes in interest rates significantly affect the volatility of Taichung's house price return, whereas such changes demonstrate nonsignificant effects on the other cities' volatilities of house price returns. The information in Tables 10 and 11 imply that in terms of using monetary policy to exert control over the housing markets of major cities in Taiwan, supply is more effective than price (interest rate), which affects housing markets nonsignificantly. Previous studies have discovered the influence of macroprudential policy on housing markets, for example, Belke et al. (2008) found that excess monetary liquidity affects housing prices more than consumer prices in the Euro area and the USA. Tsai (2015) used data of house prices in the U.S. from January 1991 to August 2012 to explore the correlations between monetary liquidity and house 

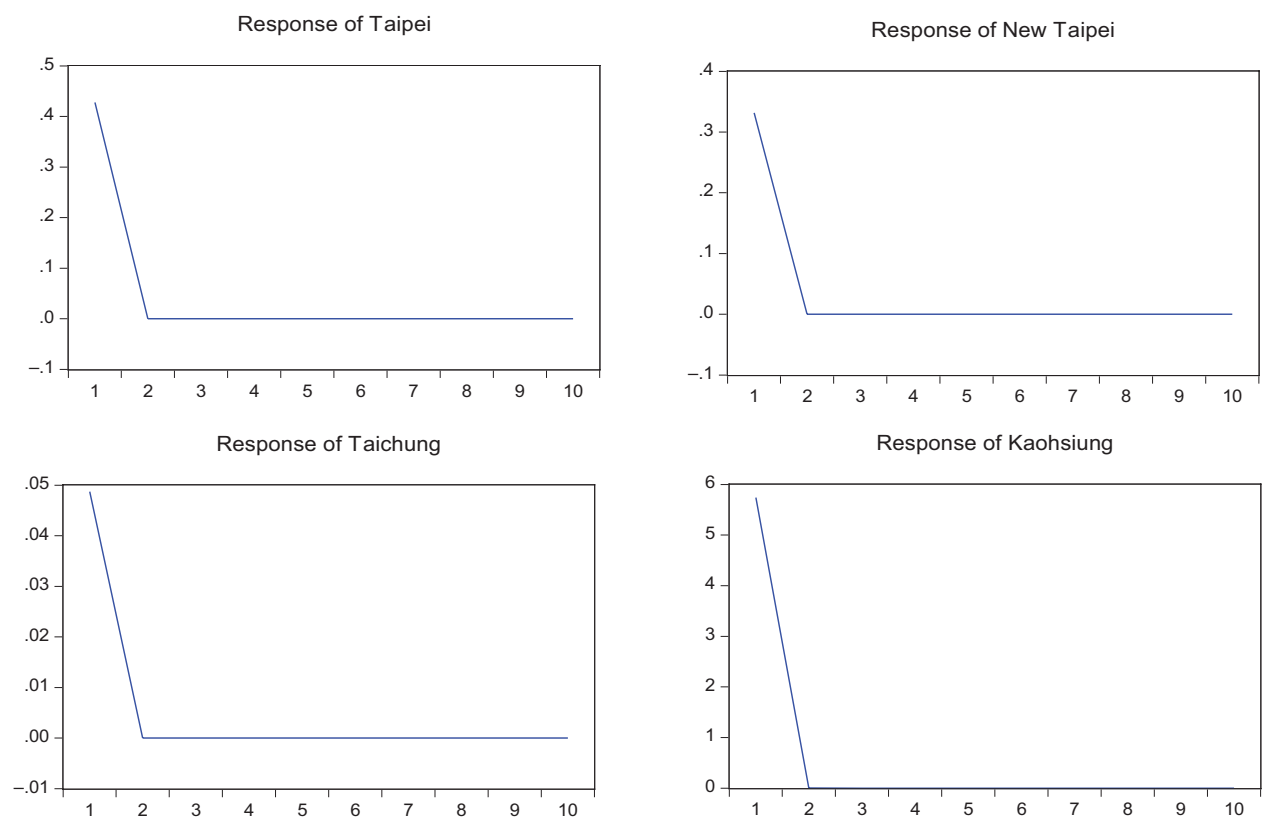

Figure 6. Response of housing market volatility on the shock from money supply

price bubbles in the U.S. housing market, and found that the housing market returns are significantly correlated to monetary supplies. The results of this part of the study are consistent with those reported in the literature, indicating the strong influence of money supply; therefore, macroprudential policy can be adopted when intervening in the housing market.

Based on the information in Tables 9 and 12, stock price returns significantly and positively influence the four cities' house price returns, indicating that the wealth effect is significant in Taiwanese housing markets. However, favorable performance in stock markets leads to housing market volatility risk; for example, such performance increases volatility in New Taipei and Kaohsiung's house price returns. In summary, the results in Tables 7-12 reveal that the sources of Taipei's housing market risk are significantly affected only by money supply, whereas those of the other three cities' housing market risks are significantly affected by other factors in addition to money supply. The sources of Taichung's housing market risk are affected by interest rates, and those of New Taipei and Kaohsiung's housing market risks are affected by stock returns. According to the analysis result in step 3, we reveal the fourth advantage of Taipei's housing market serving as a safe haven for investments in Taiwanese markets, namely that Taipei's housing market risk tends not to be influenced by external shocks.

\section{Conclusions}

We analyze four major cities' housing markets in northern (Taipei and New Taipei), central (Taichung), and southern (Kaohsiung) Taiwan and explore risk transmission among and sources of risks in these housing markets. Our analy- sis involves using Taipei as a sample to discuss whether an emerging market or economic and financial hub can serve as a safe haven when house prices are extremely high. Accordingly, this study investigates the risk characteristics of Taipei's housing market by dividing the analysis into three steps.

First, in step 1, we examine the correlations among the four cities' housing markets and Taiwan's overall housing market and identify two advantages of Taipei's housing market, namely lower volatility risk and stronger momentum (continuity) of increasing prices. Subsequently, in step 2, we explore the correlation in each pair of cities within the four cities and reveal that Taipei's house price returns unidirectionally and positively lead all the other cities except for New Taipei. Regarding risk, Taipei's housing market transmits risks to Taichung and Kaohsiung's housing markets, whereas no city's housing market transmits risks to Taipei's housing market. Based on these findings, this study proposes the third advantage of Taipei's housing market serving as a safe haven for investments in Taiwanese housing markets, namely spillover effects and lack of susceptibility to volatility in other cities' housing markets.

Finally, in step 3, we discuss the correlations between cities' house prices and macroeconomic shocks and discover that the sources of Taipei's housing market risk are significantly influenced only by money supply. By contrast, the sources of the other three cities' housing market risks are influenced by other factors as well as money supply. Therefore, this study uncovers the fourth advantage of Taipei's housing market serving as a safe haven for investments in Taiwanese markets, namely relatively high immunity to external shocks.

Previous studies have emphasized discussions on Taipei's housing bubble. The present study obtains a result 
suggesting that despite having the highest house prices and largest market bubble, Taipei's housing market exhibits the lowest house price volatility risk, and thus is the safest market for housing investments. This result explains why the highest proportion of people buying houses for investment purposes is observed in Taipei and people buying houses in Kaohsiung tend to accept high investment risk because they buy houses primarily for self-residence.

Lee (2003) analyzes the housing systems in Hong Kong, Singapore, Taiwan, and South Korea, discovering a vast disparity between the housing culture of East Asian economies and that of Western industrial economies. In addition, an economy with some regions exhibiting excessive housing market development is a commonly observed phenomenon in Asian and emerging markets. For example, Singapore and Hong Kong are markets with highly developed financial industries and high house prices; China is the world's largest emerging economy, with excessively concentrated housing market development in Beijing (capital) and Shanghai (financial hub).

Eraslan (2016) finds that the high hedging demand for housing in London, the world's financial center, has led to a constant rise in the city's housing prices. Accordingly, this study uses a similar perspective to examine whether the same effect (economic and financial centers) has resulted in low risk of housing price volatility of high housing prices in certain areas of Taiwan and whether the funds attracting investment have led to disequilibrium in housing market development. According to the analysis results, this study proposes a reason for such unbalanced resource allocation in housing markets: investment money flows into regions where development is highly concentrated, regardless of their overexuberant housing markets or government warnings of their high housing market risks, because from the perspective of safe-haven and investment demands, a safe-haven housing market for money exists only in an economy's financial hub.

\section{Acknowledgments}

We are immensely grateful to Professor Audrius Banaitis (Editor) and the two anonymous referees for the constructive comments of this paper. We also thank the Chinese Society of Housing Studies for providing funding that enables the continuation of this research and the dissemination of these results.

\section{References}

Andersson, D. E., Shyr, O. F., \& Fu, J. (2010). Does high-speed rail accessibility influence residential property prices? Hedonic estimates from southern Taiwan. Journal of Transport Geography, 18(1), 166-174.

https://doi.org/10.1016/j.jtrangeo.2008.10.012

Andreasson, P., Bekiros, S., Nguyen, D. K., \& Uddin, G. S. (2016). Impact of speculation and economic uncertainty on commodity markets. International Review of Financial Analysis, 43, 115-127. https://doi.org/10.1016/j.irfa.2015.11.005
Andersen, T. G., Bollerslev, T., Diebold, F. X., \& Vega, C. (2007). Real-time price discovery in global stock, bond and foreign exchange markets. Journal of International Economics, 73(2), 251-277. https://doi.org/10.1016/j.jinteco.2007.02.004

Baele, L., Bekaert, G., \& Inghelbrecht, K. (2010). The determinants of stock and bond return comovements. Review of Financial Studies, 23(6), 2374-2428. https://doi.org/10.1093/rfs/hhq014

Barros, C. P., Gil-Alana, L. A., \& Payne, J. E. (2015). Modeling the long memory behavior in U.S. housing price volatility. Journal of Housing Research, 24(1), 87-106.

Bekiros, S. D. (2014). Exchange rates and fundamentals: comovement, long-run relationships and short-run dynamics. Journal of Banking \& Finance, 39, 117-134. https://doi.org/10.1016/j.jbankfin.2013.11.007

Belke, A. H., Orth, W., \& Setzer, R. (2008). Global liquidity and house prices: a VAR analysis for OECD countries. Paper presented at the 21st Australasian Finance and Banking Conference, Sydney, Australia. https://doi.org/10.2139/ssrn.1096525

Bourassa, S. C., Hoesli, M., \& Oikarinen, E. (2019). Measuring house price bubbles. Real Estate Economics, 47(2), 534-563. https://doi.org/10.1111/1540-6229.12154

Cesa-Bianchi, A., Cespedes, L. F., \& Rebucci, A. (2015). Global liquidity, house prices, and the macroeconomy: evidence from advanced and emerging economies. Journal of Money, Credit and Banking, 47(S1), 301-335.

https://doi.org/10.1111/jmcb.12204

Chandler, D., \& Disney, R. (2014). The housing market in the United Kingdom: effects of house price volatility on households. Fiscal Studies, 35(3), 371-394. https://doi.org/10.1111/j.1475-5890.2014.12034.x

Chang, C.-O., \& Chen, M.-C. (2015). Taiwan: housing bubbles and affordability. In A. Bardhan, R. H. Edelstein, \& C. A. Kroll (Eds.), Global housing markets: crises, policies, and institutions (pp. 447-463). Wiley. https://doi.org/10.1002/9781119200505.ch20

Chen, M.-C., Tsai, I.-C., \& Chang, C.-O. (2007). House prices and household income: do they move apart? Evidence from Taiwan. Habitat International, 31(2), 243-256. https://doi.org/10.1016/j.habitatint.2007.02.005

Ciner, C., Gurdgiev, C., \& Lucey, B. M. (2013). Hedges and safe havens: an examination of stocks, bonds, gold, oil and exchange rates. International Review of Financial Analysis, 29, 202-211. https://doi.org/10.1016/j.irfa.2012.12.001

Conrad, C., \& Karanasos, M. (2006). The impulse response function of the long memory GARCH process. Economics Letters, 90(1), 34-41. https://doi.org/10.1016/j.econlet.2005.07.001

Coskun, Y., Seven, U., Ertugrul, H. M., \& Alp, A. (2020). Housing price dynamics and bubble risk: the case of Turkey. Housing Studies, 35(1), 50-86.

https://doi.org/10.1080/02673037.2017.1363378

De Vries, P., \& Boelhouwer, P. (2009). Equilibrium between interest payments and income in the housing market. Journal of Housing and the Built Environment, 24(1), 19-29. https://doi.org/10.1007/s10901-008-9131-Z

Dicle, M. F., \& Levendis, J. (2017). Hedging market volatility with gold. Quantitative Finance and Economics, 1(3), 253-271. https://doi.org/10.3934/QFE.2017.3.253

Elder, J. (2003). An impulse-response function for a vector autoregression with multivariate GARCH-in-mean. Economics Letters, 79(1), 21-26. https://doi.org/10.1016/S0165-1765(02)00283-5

Eraslan, S. (2016). Safe-haven demand for housing in London. Economic Modelling, 58, 482-493.

https://doi.org/10.1016/j.econmod.2015.12.022 
Gallin, J. (2008). The long-run relationship between house prices and rents. Real Estate Economics, 36(4), 635-658. https://doi.org/10.1111/j.1540-6229.2008.00225.x

Gholipour, H. F., \& Lean, H. H. (2017). Ripple effect in regional housing and land markets in Iran: implications for portfolio diversification. International Journal of Strategic Property Management, 21(4), 331-345.

https://doi.org/10.3846/1648715X.2016.1272010

Glascock, J. L., Michayluk, D., \& Neuhauser, K. (2004). The riskiness of REITs surrounding the October 1997 stock market decline. Journal of Real Estate Finance and Economics, 28(4), 339-354. https://doi.org/10.1023/B:REAL.0000018786.39272.fa

Habib, M. M., \& Stracca, L. (2012). Getting beyond carry trade: what makes a safe haven currency? Journal of International Economics, 87(1), 50-64.

https://doi.org/10.1016/j.jinteco.2011.12.005

Hafner, C. M., \& Herwartz, H. (2006). Volatility impulse responses for multivariate GARCH models: an exchange rate illustration. Journal of International Money and Finance, 25(5), 719-740. https://doi.org/10.1016/j.jimonfin.2006.04.006

Hartzell, D., Hekman, J. S., \& Miles, M. E. (1987). Real estate returns and inflation. Real Estate Economics, 15(1), 617-637. https://doi.org/10.1111/1540-6229.00407

Himmelberg, C., Mayer, C., \& Sinai, T. (2005). Assessing high house prices: bubbles, fundamentals and misperceptions. Journal of Economic Perspectives, 19(4), 67-92. https://doi.org/10.1257/089533005775196769

Hott, C., \& Monnin, P. (2008). Fundamental real estate prices: an empirical estimation with international data. Journal of Real Estate Finance and Economics, 36(4), 427-450. https://doi.org/10.1007/s11146-007-9097-8

Hulchanski, J. D. (1995). The concept of housing affordability: six contemporary uses of the housing expenditure-to-income ratio. Housing Studies, 10(4), 471-491. https://doi.org/10.1080/02673039508720833

Jiang, J., Marsh, T. L., \& Tozer, P. R. (2015). Policy induced price volatility transmission: linking the U.S. crude oil, corn and plastics markets. Energy Economics, 52, 217-227. https://doi.org/10.1016/j.eneco.2015.10.008

Kang, H.-H., \& Liu, S. B. (2014). The impact of the 2008 financial crisis on housing prices in China and Taiwan: a quantile regression analysis. Economic Modelling, 42, 356-362.

https://doi.org/10.1016/j.econmod.2014.07.018

Karolyi, G. A. (1995). A multivariate GARCH model of international transmissions of stock returns and volatility: the case of the United States and Canada. Journal of Business \& Economic Statistics, 13(1), 11-25.

https://doi.org/10.1080/07350015.1995.10524575

Kopyl, K. A., \& Lee, J. B.-T. (2016). How safe are the safe haven assets? Financial Markets and Portfolio Management, 30(4), 453-482. https://doi.org/10.1007/s11408-016-0277-5

Lee, J. (2003). Is there an East Asian housing culture? Contrasting housing systems of Hong Kong, Singapore, Taiwan and South Korea. Journal of Comparative Asian Development, 2(1), 3-19. https://doi.org/10.1080/15339114.2003.9678369

Le Pen, Y., \& Sévi, B. (2010). Volatility transmission and volatility impulse response functions in European electricity forward markets. Energy Economics, 32(4), 758-770. https://doi.org/10.1016/j.eneco.2009.12.003
Li, W. D.-H. (2002). The growth of mass home ownership in Taiwan. Journal of Housing and the Built Environment, 17(1), 21-32. https://doi.org/10.1023/A:1014812822953

Lin, P.-T., \& Fuerst, F. (2014). Volatility clustering, risk-return relationship, and asymmetric adjustment in the Canadian housing market. Journal of Real Estate Portfolio Management, 20(1), 37-46.

Liu, H.-H., \& Chen, S.-H. (2016). Nonlinear relationships and volatility spillovers among house prices, interest rates and stock market prices. International Journal of Strategic Property Management, 20(4), 371-383.

https://doi.org/10.3846/1648715X.2016.1191557

Malpezzi, S. (1999). A simple error correction model of house prices. Journal of Housing Economics, 8(1), 27-62. https://doi.org/10.1006/jhec.1999.0240

Pavlidis, E., Yusupova, A., Paya, I., Peel, D., Martínez-García, E., Mack, A., \& Grossman, V. (2016). Episodes of exuberance in housing markets: in search of the smoking gun. Journal of Real Estate Finance and Economics, 53(4), 419-449. https://doi.org/10.1007/s11146-015-9531-2

Ranaldo, A., \& Söderlind, P. (2010). Safe haven currencies. Review of Finance, 14(3), 385-407. https://doi.org/10.1093/rof/rfq007

Rubens, J., Bond, M., \& Webb, J. (1989). The inflation-hedging effectiveness of real estate. Journal of Real Estate Research, 4(2), 45-55.

Scatigna, M., Szemere, R., \& Tsatsaronis, K. (2014). Residential property price statistics across the globe. BIS Quarterly Review, 73, 61-76.

Sogiakas, V., \& Karathanassis, G. (2015). Informational efficiency and spurious spillover effects between spot and derivatives markets. Global Finance Journal, 27, 46-72. https://doi.org/10.1016/j.gfj.2015.04.004

Teng, H.-J., Chang, C.-O., \& Chau, K. W. (2013). Housing bubbles: a tale of two cities. Habitat International, 39, 8-15. https://doi.org/10.1016/j.habitatint.2012.10.009

Tsai, I.-C. (2015). Monetary liquidity and the bubbles in the U.S. housing market. International Journal of Strategic Property Management, 19(1), 1-12.

https://doi.org/10.3846/1648715X.2014.973465

Tsai, I.-C. (2018). Housing price convergence, transportation infrastructure and dynamic regional population relocation. Habitat International, 79, 61-73. https://doi.org/10.1016/j.habitatint.2018.07.004

Tsai, I.-C., \& Peng, C.-W. (2011). Bubbles in the Taiwan housing market: the determinants and effects. Habitat International, 35(2), 379-390. https://doi.org/10.1016/j.habitatint.2010.11.010

Tsai, I.-C., \& Chiang, S.-H. (2018). Risk transfer among housing markets in major cities in China. Sustainability, 10(7), 2386. https://doi.org/10.3390/su10072386

Vishwakarma, V. K. (2015). The dynamics of risk premium: the case of the Taiwan real estate market. Journal of Risk Finance, 16(4), 463-482. https://doi.org/10.1108/JRF-02-2015-0020

Weng, Y., \& Gong, P. (2017). On price co-movement and volatility spillover effects in China's housing markets. International Journal of Strategic Property Management, 21, 240-255. https://doi.org/10.3846/1648715X.2016.1271369

White, M. (2015). Cyclical and structural change in the UK housing market. Journal of European Real Estate Research, 8(1), 85-103. https://doi.org/10.1108/JERER-02-2014-0011 